\title{
Geochemical, stable isotope, and numerical modeling studies of sake and groundwater for identification of the location of sake production: A case study from Hakusan City, Japan
}

\author{
Shingo Tomiyama, ${ }^{1 *}$ Tomokazu Hashiguchi, ${ }^{2}$ AkiRa Ueda, ${ }^{3}$ AKIKo Kitai, ${ }^{1}$ Hanae IzU ${ }^{2}$ and Shigetoshi Sudo ${ }^{2}$ \\ ${ }^{1}$ Mitsubishi Materials Techno Corporation, 1-297 Kitabukuro-cho, Omiya-ku, Saitama 330-0835, Japan \\ ${ }^{2}$ Safety and Quality Research Division, National Research Institute of Brewing, \\ 3-7-1 Kagamiyama, Higashi-hiroshima, Hiroshima 739-0046, Japan \\ ${ }^{3}$ Graduate School of Science and Engineering, University of Toyama, Gofuku 3190, Toyama 930-8555, Japan
}

(Received May 6, 2012; Accepted August 1, 2013)

\begin{abstract}
Understanding the source and chemical characteristics of groundwater used for sake production is an important strategy for the quality management of sake brewing. Oxygen isotope ratios $\left(\delta^{18} \mathrm{O}\right)$ of 96 sake samples from 19 provinces in Japan were analyzed. A good correlation was found between the sake $\delta^{18} \mathrm{O}$ values and groundwater $\delta^{18} \mathrm{O}$ values taken from previously published data, where the $\delta^{18} \mathrm{O}$ of sake is similar to that of the groundwater used in the sake breweries.

Detailed sampling of 19 sake and groundwater samples was conducted near a sake brewery in the Hokuriku district, central northern Japan (Ishikawa and Toyama Prefectures). The $\delta^{18} \mathrm{O}$ of sake and groundwater in the area also showed a good correlation. Our findings indicate that the $\delta^{18} \mathrm{O}$ of sake can be used to identify the locality of sake production. This has the potential to help prevent fraudulent representation of the area of production.

Water chemistry, hydrogen $(\delta \mathrm{D})$ and oxygen $\left(\delta^{18} \mathrm{O}\right)$ isotopes of two groundwater and eighteen river water samples in Hakusan City, Ishikawa Prefecture, were analyzed to determine their origin and water flow patterns. The groundwater is of a $\mathrm{Ca}-\mathrm{HCO}_{3}$ type similar to river water. The results show that the groundwater used to produce the "Hakusan" brand of sake originates from river water at an altitude of 360 to $450 \mathrm{~m}$. This is supported by groundwater flow modeling, which also indicates that the water was sourced $2-3 \mathrm{~km}$ away from the sake brewery. The combined geochemical and numerical modeling approach provides a good tool for determining the source of groundwater used in sake production.
\end{abstract}

Keywords: sake, oxygen isotope, Ishikawa, groundwater, modeling

\section{INTRODUCTION}

Large quantities of good quality groundwater are used for sake brewing. Groundwater contains several dissolved chemical components. Potassium is known to promote yeast fermentation, and calcium aids the extraction of koji enzymes (Brewing Society of Japan, 1996). The quality of sake is affected by the chemical composition of the local groundwater used in the brewing process. In recent times, fraudulent representation of the location of sake production and other products in the food sector has increased. Trace element and DNA analyses have been used to trace the origins of food products (e.g., Dion et al., 2008; Adamo et al., 2012), as well as stable isotope ratio analyses of light elements (Ueki, 2008; Nakashita et al., 2008; Suzuki et al., 2008). In addition, consumers are

\footnotetext{
*Corresponding author (e-mail: tomiyama@mmc.co.jp)

Copyright () 2013 by The Geochemical Society of Japan.
}

increasingly expecting disclosure of the source of groundwater used for beverage production. Case studies of mineral waters from the flank of Mt. Fuji and the Gifu and Kanto plains have been conducted, including analysis of the stable isotopic compositions and numerical modeling of groundwater and river waters (e.g., Tomiyama et al., 2009, 2010, 2011). However, a detailed study for sake has not yet been undertaken. Regulations have been put in place requiring producers to provide geographical information on bottle labels for the purpose of establishing regional brands and to provide appropriate information to consumers (National Tax Agency Notice No. 4, December 28, 1994). The sake brewed and manufactured in Hakusan City, in the northern part of central Japan is known by the brand name "Hakusan."

There are many previous studies that traced the geographical sources of foods including water, wine, and milk by using multi-elemental and multi-isotope analyses (e.g., Kelly et al., 2005; Marisa et al., 2004; Chesson et al., 2010). Crittenden et al. (2007) evaluated the suitability of multi-element isotope ratio analysis for determining 
Table 1. $\delta^{18} O$ values of sake in Japan

\begin{tabular}{|c|c|c|c|c|}
\hline Sample No. & Sampling date* & Locality & $\begin{array}{c}\delta^{18} \mathrm{O} \text { of sake } \\
\text { (observed) }\end{array}$ & $\begin{array}{r}\delta^{18} \mathrm{O} \text { of groundwater and river water** } \\
\text { (estimated) }\end{array}$ \\
\hline G11-26 & 17-Jan-2011 & Asahikawa, Hokkaido & -11.5 & -12.0 \\
\hline G11-30 & 17-Jan-2011 & Oosaki, Miyagi & -9.4 & -8.0 \\
\hline G11-31 & 17-Jan-2011 & Oosaki, Miyagi & -9.5 & -8.0 \\
\hline G11-32 & 17-Jan-2011 & Oosaki, Miyagi & -9.6 & -8.0 \\
\hline G11-33 & 17-Jan-2011 & Oosaki, Miyagi & -8.6 & -8.0 \\
\hline G11-34 & 17-Jan-2011 & Nihonmatsu, Fukushima & -10.5 & -9.0 \\
\hline G10-2195 & 3-Nov-2010 & Nihonmatsu, Fukushima & -10.4 & -9.0 \\
\hline G11-294 & 17-Jan-2011 & Koriyama, Fukushima & -9.9 & -9.0 \\
\hline G11-35 & 17-Jan-2011 & Niigata, Niigata & -10.9 & -10.0 \\
\hline G11-36 & 17-Jan-2011 & Kashiwazaki, Niigata & -9.5 & -10.0 \\
\hline G11-458 & 24-Jan-2011 & Shibata, Niigata & -10.6 & -10.0 \\
\hline G11-37 & 17-Jan-2011 & Oume, Tokyo & -9.4 & -9.0 \\
\hline G11-38 & 17-Jan-2011 & Oume, Tokyo & -9.4 & -9.0 \\
\hline G11-21 & 17-Jan-2011 & Toyama, Toyama & -11.5 & -10.0 \\
\hline G11-22 & 17-Jan-2011 & Kurobe, Toyama & -11.7 & -10.0 \\
\hline G10-2189 & $3-\mathrm{Nov}-2010$ & Kaga, Ishikawa & -9.4 & -9.0 \\
\hline G10-2190 & $3-\mathrm{Nov}-2010$ & Kusu, Ishikawa & -8.9 & -9.0 \\
\hline G10-2191 & 3-Nov-2010 & Kanazawa, Ishikawa & -9.2 & -9.0 \\
\hline G10-3312 & 17-Jan-2011 & Kanazawa, Ishikawa & -9.9 & -9.0 \\
\hline G10-3313 & 17-Jan-2011 & Kanazawa, Ishikawa & -10.2 & -9.0 \\
\hline G10-3314 & 17-Jan-2011 & Kanazawa, Ishikawa & -9.0 & -9.0 \\
\hline G10-3315 & 17-Jan-2011 & Kanazawa, Ishikawa & -9.1 & -9.0 \\
\hline G10-3316 & 17-Jan-2011 & Kanazawa, Ishikawa & -9.5 & -9.0 \\
\hline G10-3317 & 17-Jan-2011 & Kanazawa, Ishikawa & -9.4 & -9.0 \\
\hline G10-3307 & 17-Jan-2011 & Kanazawa, Ishikawa & -10.2 & -9.0 \\
\hline G10-2186 & $3-\mathrm{Nov}-2010$ & Hakusan, Ishikawa & -8.8 & -9.0 \\
\hline G10-2187 & 3-Nov-2010 & Hakusan, Ishikawa & -9.3 & -9.0 \\
\hline G10-2188 & 3-Nov-2010 & Hakusan, Ishikawa & -9.5 & -9.0 \\
\hline G10-2192 & 3-Nov-2010 & Hakusan, Ishikawa & -9.3 & -9.0 \\
\hline G10-2193 & 3-Nov-2010 & Hakusan, Ishikawa & -9.4 & -9.0 \\
\hline G10-3113 & 17-Jan-2011 & Hakusan, Ishikawa & -8.8 & -9.0 \\
\hline G10-3114 & 17-Jan-2011 & Hakusan, Ishikawa & -8.7 & -9.0 \\
\hline G10-3115 & 17-Jan-2011 & Hakusan, Ishikawa & -9.1 & -9.0 \\
\hline G10-3116 & 17-Jan-2011 & Hakusan, Ishikawa & -8.8 & -9.0 \\
\hline G10-3117 & 17-Jan-2011 & Hakusan, Ishikawa & -8.2 & -9.0 \\
\hline G10-3128 & 17-Jan-2011 & Hakusan, Ishikawa & -9.3 & -9.0 \\
\hline G10-3129 & 17-Jan-2011 & Hakusan, Ishikawa & -9.4 & -9.0 \\
\hline G10-3130 & 17-Jan-2011 & Hakusan, Ishikawa & -9.5 & -9.0 \\
\hline G10-3131 & 17-Jan-2011 & Hakusan, Ishikawa & -9.0 & -9.0 \\
\hline G10-3132 & 17-Jan-2011 & Hakusan, Ishikawa & -9.4 & -9.0 \\
\hline G10-3301 & 17-Jan-2011 & Hakusan, Ishikawa & -9.2 & -9.0 \\
\hline G10-3302 & 17-Jan-2011 & Hakusan, Ishikawa & -9.4 & -9.0 \\
\hline G10-3303 & 17-Jan-2011 & Hakusan, Ishikawa & -9.4 & -9.0 \\
\hline G10-3304 & 17-Jan-2011 & Hakusan, Ishikawa & -9.3 & -9.0 \\
\hline G10-3305 & 17-Jan-2011 & Hakusan, Ishikawa & -9.5 & -9.0 \\
\hline G10-2194 & 17-Jan-2011 & Hakusan, Ishikawa & -9.1 & -9.0 \\
\hline G10-3118 & 17-Jan-2011 & Hakusan, Ishikawa & -9.2 & -9.0 \\
\hline G10-3119 & 17-Jan-2011 & Hakusan, Ishikawa & -9.2 & -9.0 \\
\hline G10-3120 & 17-Jan-2011 & Hakusan, Ishikawa & -9.3 & -9.0 \\
\hline G10-3121 & 17-Jan-2011 & Hakusan, Ishikawa & -9.5 & -9.0 \\
\hline G10-3122 & 17-Jan-2011 & Hakusan, Ishikawa & -9.2 & -9.0 \\
\hline G10-3123 & 17-Jan-2011 & Hakusan, Ishikawa & -8.8 & -9.0 \\
\hline G10-3124 & 17-Jan-2011 & Hakusan, Ishikawa & -8.7 & -9.0 \\
\hline G10-3125 & 17-Jan-2011 & Hakusan, Ishikawa & -9.0 & -9.0 \\
\hline G10-3126 & 17-Jan-2011 & Hakusan, Ishikawa & -9.0 & -9.0 \\
\hline G10-3127 & 17-Jan-2011 & Hakusan, Ishikawa & -8.9 & -9.0 \\
\hline G10-3306 & 17-Jan-2011 & Noto, Ishikawa & -8.7 & -9.0 \\
\hline G10-3308 & 17-Jan-2011 & Noto, Ishikawa & -8.8 & -9.0 \\
\hline G10-3309 & 17-Jan-2011 & Nomi, Ishikawa & -9.6 & -9.0 \\
\hline G10-3310 & 17-Jan-2011 & Tsubata, Ishikawa & -8.7 & -9.0 \\
\hline
\end{tabular}


Table 1. (continued)

\begin{tabular}{|c|c|c|c|c|}
\hline Sample No. & Sampling date* & Locality & $\begin{array}{l}\delta^{18} \mathrm{O} \text { of sake } \\
\text { (observed) }\end{array}$ & $\begin{array}{l}\delta^{18} \mathrm{O} \text { of groundwater and river water*** } \\
\text { (estimated) }\end{array}$ \\
\hline G11-23 & 17-Jan-2011 & Katuyama, Fukui & -9.4 & -9.0 \\
\hline G11-24 & 17-Jan-2011 & Obama, Fukui & -8.9 & -9.0 \\
\hline G11-25 & 17-Jan-2011 & Fukui, Fukui & -9.4 & -9.0 \\
\hline G11-27 & 17-Jan-2011 & Kiso, Nagano & -11.0 & -12.0 \\
\hline G11-28 & 17-Jan-2011 & Suwa, Nagano & -12.0 & -11.0 \\
\hline G11-29 & 17-Jan-2011 & Ina, Nagano & -10.6 & -11.0 \\
\hline G11-306 & 24-Jan-2011 & Nirasaki, Yamanashi & -10.5 & -10.0 \\
\hline G11-297 & 17-Jan-2011 & Tajimi, Gifu & -9.1 & -9.0 \\
\hline G11-299 & 17-Jan-2011 & Mizunami, Gifu & -9.0 & -9.0 \\
\hline G11-298 & 17-Jan-2011 & Hazu, Aichi & -8.1 & -9.0 \\
\hline G11-302 & 24-Jan-2011 & Kyoto, Kyoto & -7.7 & -7.5 \\
\hline G11-307 & 24-Jan-2011 & Kyoto, Kyoto & -7.9 & -8.0 \\
\hline G11-301 & 24-Jan-2011 & Nishinomiya, Hyogo & -7.4 & -7.5 \\
\hline G11-452 & 24-Jan-2011 & Nishinomiya, Hyogo & -7.6 & -8.0 \\
\hline G11-453 & 24-Jan-2011 & Nishinomiya, Hyogo & -7.5 & -8.0 \\
\hline G11-454 & 24-Jan-2011 & Kobe, Hyogo & -7.5 & -8.0 \\
\hline G11-455 & 24-Jan-2011 & Kobe, Hyogo & -8.0 & -8.0 \\
\hline G11-456 & 24-Jan-2011 & Kobe, Hyogo & -7.8 & -8.0 \\
\hline G11-303 & 17-Jan-2011 & Tsuyama, Okayama & -8.3 & -8.0 \\
\hline G11-304 & 17-Jan-2011 & Tsuyama, Okayama & -8.3 & -8.0 \\
\hline G11-305 & 17-Jan-2011 & Tsuyama, Okayama & -7.9 & -8.0 \\
\hline G11-451 & 24-Jan-2011 & Futukaichi, Hiroshima & -8.0 & -8.0 \\
\hline G10-2888 & 11-Jan-2011 & Higashi-hiroshima, Hiroshima & -7.7 & -8.0 \\
\hline G10-2889 & 11-Jan-2011 & Higashi-hiroshima, Hiroshima & -7.7 & -8.0 \\
\hline G10-2890 & 11-Jan-2011 & Higashi-hiroshima, Hiroshima & -7.6 & -8.0 \\
\hline G10-2891 & 11-Jan-2011 & Higashi-hiroshima, Hiroshima & -7.6 & -8.0 \\
\hline G10-2892 & 11-Jan-2011 & Higashi-hiroshima, Hiroshima & -7.8 & -8.0 \\
\hline G11-457 & 24-Jan-2011 & Higashi-hiroshima, Hiroshima & -8.4 & -8.0 \\
\hline G11-308 & 24-Jan-2011 & Higashi-hiroshima, Hiroshima & -8.4 & -8.0 \\
\hline G10-2196 & 3-Nov-2010 & Yasuda, Kochi & -7.4 & -7.0 \\
\hline G11-39 & 17-Jan-2011 & Sagawa, Kochi & -7.3 & -7.0 \\
\hline G11-40 & 17-Jan-2011 & Sagawa, Kochi & -7.5 & -7.0 \\
\hline G11-295 & 17-Jan-2011 & Kami, Kochi & -7.3 & -7.0 \\
\hline G11-296 & 17-Jan-2011 & Kochi, Kochi & -8.1 & -7.0 \\
\hline G11-300 & 24-Jan-2011 & Kumamoto, Kumamoto & -7.3 & -7.5 \\
\hline G11-459 & 24-Jan-2011 & Uruma, Okinawa & -5.7 & -4.9 \\
\hline
\end{tabular}

* Collected sake samples bottled at the sake brewery.

**The $\delta^{18} O$ values of nearby groundwater and rivers were estimated from figure 3 of Mizota and Kusakabe (1994) and averaged data from Agata et al. (2001).

the source of cow milk produced in Australasia. They showed that the oxygen isotope ratio $\left(\delta^{18} \mathrm{O}\right)$ and carbon isotope ratio $\left(\delta^{13} \mathrm{C}\right)$ reflected isotopic variations due to latitudinal and climatic variability in different regions, and concluded that isotope analysis can help identify the geographic source of dairy products. Papesch and Horacek (2009) examined the $\delta^{18} \mathrm{O}$ of water in beer and demonstrated that a sample of beer labeled as premium brand was, in reality, an inferior brand. Suzuki et al. (2008) examined the carbon and nitrogen contents and the $\delta^{18} \mathrm{O}$, $\delta^{13} \mathrm{C}$, and $\left(\delta^{14} \mathrm{~N}\right)$ isotope ratio of polished rice in order to develop a simple method to determine its geographical source. They showed that such chemical and isotopic parameters were potentially useful for rapid and regular dis- crimination of geographical source of the polished rice.

In this study, the $\delta^{18} \mathrm{O}$ of sake samples from all over Japan were analyzed for the first time. The $\delta^{18} \mathrm{O}$ of the sake samples was compared to the $\delta^{18} \mathrm{O}$ values reported in the literature for shallow groundwater and river water near the sake breweries (Mizota and Kusakabe, 1994; Agata et al., 2001). A detailed analysis of the $\delta^{18} \mathrm{O}$ of sake and the $\delta^{18} \mathrm{O}$, hydrogen isotopes $(\delta \mathrm{D})$, and other geochemical characteristics of groundwater samples from the Hokuriku district, northern central Japan, was also conducted. The data were used to determine the source of groundwater used for brewing "Hakusan" sake. $\mathrm{Nu}$ merical modeling was also applied to estimate the history of the groundwater used in the sake brewery. 


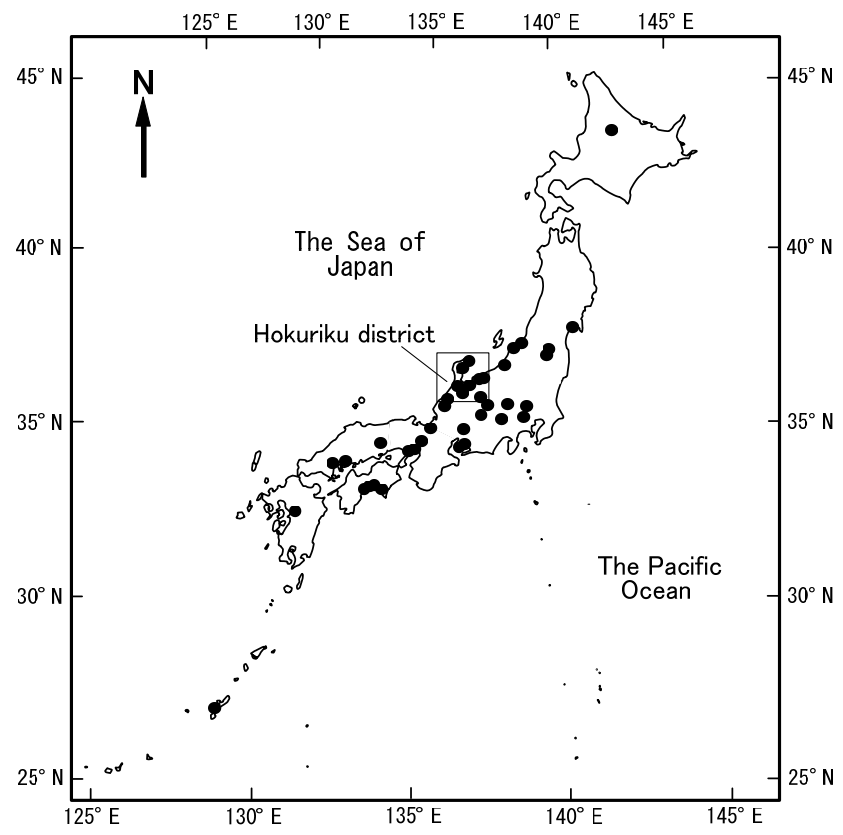

Fig. 1. Locations of sake samples in this study. The study area (Hokuriku district) is shown in the inset.

\section{SAKE AND GROUNDWATER SAMPLE LOCATIONS}

Ninety six sake samples were collected in Japan during November 2010 to January 2011 (Fig. 1) and analyzed for $\delta^{18} \mathrm{O}$. These were then compared with $\delta^{18} \mathrm{O}$ values of groundwater and river water reported by Mizota and Kusakabe (1994) and Agata et al. (2001) (Table 1). We found a good correlation between the $\delta^{18} \mathrm{O}$ of sake and groundwater collected in the same area.

Nineteen sake and groundwater samples were obtained from 17 sake breweries in central northern Japan (Ishikawa and Toyama Prefectures) in April-May 2011 (Table 2 and Fig. 2). In order to examine the source of groundwater and the mode of water flow around the sake brewery, two groundwaters and eighteen river waters were collected in Hakusan City, Ishikawa Prefecture (Table 3 and Fig. 3$)$ for chemical and stable isotope analyses $(\delta \mathrm{D}$ and $\delta^{18} \mathrm{O}$ ). The river water samples are divided into three groups based on their location: alluvial fan (D-T), talus (DGf), or hill (AGf) (Table 3 and Fig. 3).

Hakusan City is located in the western part of Ishikawa prefecture alongside the Tedori River. This river flows within the Tedori alluvial fan, which spreads between Nomi City and the southern part of Kanazawa City. Figure 3 shows the study area and water sampling sites. The alluvial fan has an area of $191 \mathrm{~km}^{2}$ and its catchment area is greater than $750 \mathrm{~km}^{2}$. The main fan has a concentric shape, and the elevation and slope of the ground are about

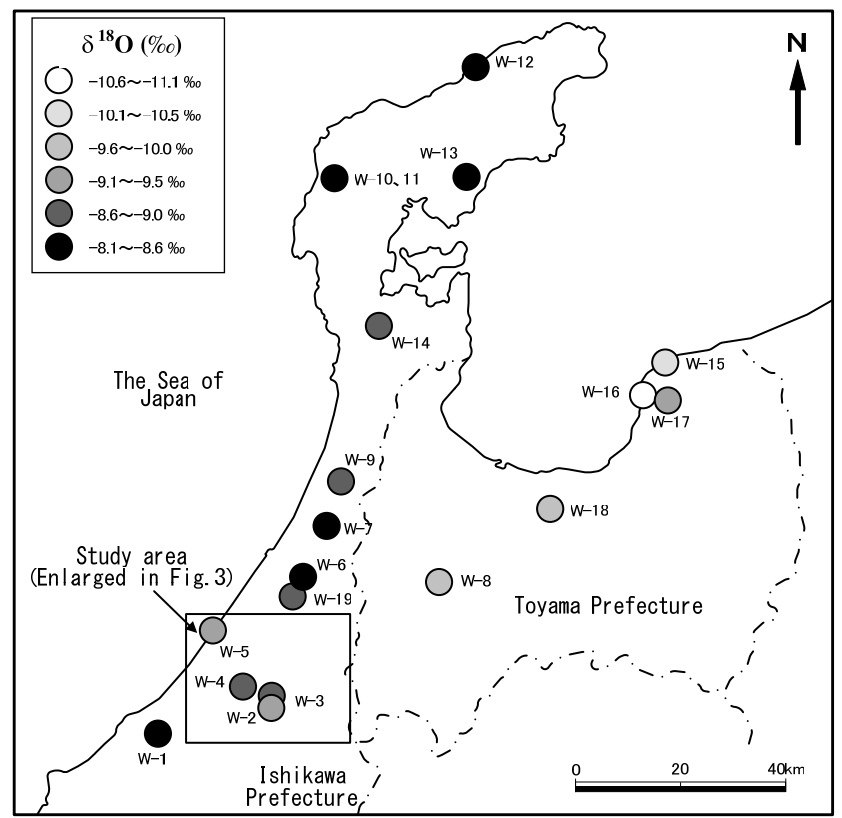

Fig. 2. Locality of sake and groundwater samples in the Hokuriku district. The $\delta^{18} \mathrm{O}$ values of groundwaters are divided into 6 groups as shown by marks with an interval of 0.5\%o. The Hakusan area is shown in the inset.

$90 \mathrm{~m}$ and $1 / 130$ at the top, and $5 \mathrm{~m}$ and $1 / 200$ at the edge, respectively (Tsuchihara et al., 2011). The basement of the study area consists of (from lower to upper layers): Miocene green tuff and rhyolite, Pleistocene sedimentary layers (lower layer of sand gravel (D-T), clay, and upper alluvial gravel (DGf)) and alluvial sand gravel deposits (AGf) (Hokuriku Agriculture Report, 1977). The groundwaters are also divided into three groups: D-T, DGf, and AGf. The groups DGf and AGf correspond to deep and shallow groundwaters, respectively (Watanabe, 2002).

There are 20 sake breweries in the southern part of the Ishikawa prefecture, many of which operate in the Tedori alluvial fan. The sake brewery studied in this work is situated on the flank (190 $\mathrm{m}$ in altitude) of a hill along the Tedori River, $7 \mathrm{~km}$ inland from the tip of the fan (Fig. 3 ). The groundwater used in the brewery is pumped from a well $100 \mathrm{~m}$ deep.

\section{Analytical Procedures}

At the sampling site, $\mathrm{pH}$, electrical conductivity (EC), and oxidation reduction potential (ORP) were measured using a pH meter (Shindengen, KS-701), EC meter (Horiba, B-173), and ORP meter (TOA, RM-12P), respectively. Dissolved ion concentrations were measured using conventional methods. All geochemical water analy- 
Table 2. $\delta^{18} \mathrm{O}$ values of sake and groundwaters from the Hokuriku district. Numbers of sake brewery correspond to those in Fig. 2

\begin{tabular}{|c|c|c|c|c|c|c|c|}
\hline \multirow[t]{2}{*}{ Brewery No. } & \multirow[t]{2}{*}{ Locality } & \multicolumn{3}{|c|}{ Sake } & \multicolumn{3}{|c|}{ Groundwater } \\
\hline & & Sampling date* & $\begin{array}{l}\text { Observed } \\
\left.\delta^{18} \mathrm{O}(\%)\right)\end{array}$ & $\begin{array}{c}\text { Averaged** } \\
\delta^{18} \mathrm{O}(\% \circ)\end{array}$ & Sampling date & Sample No. & $\begin{array}{l}\text { Observed } \\
\delta^{18} \mathrm{O}(\% o)\end{array}$ \\
\hline A & Wajima, Ishikawa & 30-Apr-2011 & -8.5 & -8.7 & 30-Apr-2011 & $\mathrm{W}-10$ & -8.1 \\
\hline A & Wajima, Ishikawa & 30-Apr-2011 & -8.7 & -8.7 & 30-Apr-2011 & $\mathrm{W}-10$ & -8.1 \\
\hline $\mathrm{A}$ & Wajima, Ishikawa & 30-Apr-2011 & -8.8 & -8.7 & 30-Apr-2011 & $\mathrm{W}-10$ & -8.1 \\
\hline B & Wajima, Ishikawa & 30-Apr-2011 & -8.2 & -8.1 & 30-Apr-2011 & $\mathrm{W}-12$ & -8.3 \\
\hline B & Wajima, Ishikawa & 30-Apr-2011 & -8.0 & -8.1 & 30-Apr-2011 & $\mathrm{W}-12$ & -8.3 \\
\hline $\mathrm{C}$ & Noto, Ishikawa & 30-Apr-2011 & -8.8 & -8.1 & 30-Apr-2011 & $\mathrm{W}-13$ & -8.3 \\
\hline $\mathrm{D}$ & Nakanoto, Ishikawa & 1-May-2011 & -9.0 & -9.0 & 1-May-2011 & $\mathrm{W}-14$ & -8.6 \\
\hline $\mathrm{D}$ & Nakanoto, Ishikawa & 1-May-2011 & -9.0 & -9.0 & 1-May-2011 & $\mathrm{W}-14$ & -8.6 \\
\hline $\mathrm{E}$ & Kaga, Ishikawa & 3-Nov-2010 & -9.4 & -9.4 & 28-Apr-2011 & $\mathrm{W}-1$ & -8.2 \\
\hline E & Kaga, Ishikawa & 28-Apr-2011 & -9.3 & -9.4 & 28-Apr-2011 & $\mathrm{W}-1$ & -8.2 \\
\hline E & Kaga, Ishikawa & 28-Apr-2011 & -9.5 & -9.4 & 28-Apr-2011 & $\mathrm{W}-1$ & -8.2 \\
\hline F & Kanzawa, Ishikawa & 17-Jan-2011 & -9.0 & -9.1 & 28-Apr-2011 & $\mathrm{W}-6$ & -8.2 \\
\hline $\mathrm{F}$ & Kanzawa, Ishikawa & 17-Jan-2011 & -9.1 & -9.1 & 28-Apr-2011 & $\mathrm{W}-6$ & -8.2 \\
\hline $\mathrm{G}$ & Kanzawa, Ishikawa & 17-Jan-2011 & -9.5 & -9.4 & 1-May-2011 & $\mathrm{W}-19$ & -8.9 \\
\hline G & Kanzawa, Ishikawa & 17-Jan-2011 & -9.4 & -9.4 & 1-May-2011 & $\mathrm{W}-19$ & -8.9 \\
\hline G & Kanzawa, Ishikawa & 3-Nov-2010 & -9.2 & -9.4 & 1-May-2011 & $\mathrm{W}-19$ & -8.9 \\
\hline $\mathrm{H}$ & Tsubata, Ishikawa & 17-Jan-2011 & -8.7 & -8.7 & 28-Apr-2011 & $\mathrm{W}-7$ & -8.2 \\
\hline $\mathrm{H}$ & Tsubata, Ishikawa & 17-Jan-2011 & -8.7 & -8.7 & 28-Apr-2011 & $\mathrm{W}-7$ & -8.2 \\
\hline I & Hakusan, Ishikawa & 17-Jan-2011 & -9.3 & -9.3 & 28-Apr-2011 & W-3 & -9.0 \\
\hline I & Hakusan, Ishikawa & 17-Jan-2011 & -9.4 & -9.3 & 28-Apr-2011 & $\mathrm{W}-3$ & -9.0 \\
\hline I & Hakusan, Ishikawa & 17-Jan-2011 & -9.2 & -9.3 & 28-Apr-2011 & $\mathrm{W}-3$ & -9.0 \\
\hline I & Hakusan, Ishikawa & 17-Jan-2011 & -9.2 & -9.3 & 28-Apr-2011 & W-3 & -9.0 \\
\hline I & Hakusan, Ishikawa & 17-Jan-2011 & -9.3 & -9.3 & 28-Apr-2011 & $\mathrm{W}-3$ & -9.0 \\
\hline I & Hakusan, Ishikawa & 17-Jan-2011 & -9.5 & -9.3 & 28-Apr-2011 & $\mathrm{W}-3$ & -9.0 \\
\hline I & Hakusan, Ishikawa & 17-Jan-2011 & -9.2 & -9.3 & 28-Apr-2011 & W-3 & -9.0 \\
\hline $\mathrm{J}$ & Hakusan, Ishikawa & 3-Nov-2010 & -8.8 & -8.9 & 28-Apr-2011 & $\mathrm{W}-4$ & -8.7 \\
\hline $\mathrm{J}$ & Hakusan, Ishikawa & 17-Jan-2011 & -8.8 & -8.9 & 28-Apr-2011 & $\mathrm{W}-4$ & -8.7 \\
\hline $\mathrm{J}$ & Hakusan, Ishikawa & 17-Jan-2011 & -8.7 & -8.9 & 28-Apr-2011 & $\mathrm{W}-4$ & -8.7 \\
\hline $\mathrm{J}$ & Hakusan, Ishikawa & 17-Jan-2011 & -9.0 & -8.9 & 28-Apr-2011 & $\mathrm{W}-4$ & -8.7 \\
\hline $\mathrm{J}$ & Hakusan, Ishikawa & 17-Jan-2011 & -9.0 & -8.9 & 28-Apr-2011 & $\mathrm{W}-4$ & -8.7 \\
\hline $\mathrm{J}$ & Hakusan, Ishikawa & 17-Jan-2011 & -8.9 & -8.9 & 28-Apr-2011 & $\mathrm{W}-4$ & -8.7 \\
\hline $\mathrm{K}$ & Hakusan, Ishikawa & 17-Jan-2011 & -9.2 & -9.4 & 28-Apr-2011 & $\mathrm{W}-5$ & -9.5 \\
\hline $\mathrm{K}$ & Hakusan, Ishikawa & 17-Jan-2011 & -9.4 & -9.4 & 28-Apr-2011 & $\mathrm{W}-5$ & -9.5 \\
\hline $\mathrm{K}$ & Hakusan, Ishikawa & 3-Nov-2010 & -9.4 & -9.4 & 28-Apr-2011 & $W-5$ & -9.5 \\
\hline $\mathrm{K}$ & Hakusan, Ishikawa & 3-Nov-2010 & -9.3 & -9.4 & 28-Apr-2011 & $\mathrm{W}-5$ & -9.5 \\
\hline $\mathrm{K}$ & Hakusan, Ishikawa & 3-Nov-2010 & -9.5 & -9.4 & 28-Apr-2011 & W-5 & -9.5 \\
\hline $\mathrm{L}$ & Hakusan, Ishikawa & 3-Nov-2010 & -9.3 & -9.3 & 28-Apr-2011 & $\mathrm{W}-5$ & -9.5 \\
\hline $\mathrm{L}$ & Hakusan, Ishikawa & 17-Jan-2011 & -9.4 & -9.3 & 28-Apr-2011 & $\mathrm{W}-5$ & -9.5 \\
\hline $\mathrm{L}$ & Hakusan, Ishikawa & 17-Jan-2011 & -9.5 & -9.3 & 28-Apr-2011 & $W-5$ & -9.5 \\
\hline $\mathrm{L}$ & Hakusan, Ishikawa & 17-Jan-2011 & -9.0 & -9.3 & 28-Apr-2011 & $\mathrm{W}-5$ & -9.5 \\
\hline $\mathrm{L}$ & Hakusan, Ishikawa & 17-Jan-2011 & -9.4 & -9.3 & 28-Apr-2011 & W-5 & -9.5 \\
\hline M & Asahi, Toyama & 1-May-2011 & -9.7 & -9.7 & 1-May-2011 & $\mathrm{W}-15$ & -10.3 \\
\hline $\mathrm{N}$ & Kurobe, Toyama & 1-May-2011 & -11.7 & -11.7 & 1-May-2011 & $\mathrm{W}-16$ & -11.1 \\
\hline $\mathrm{N}$ & Kurobe, Toyama & 1-May-2011 & -11.6 & -11.7 & 1-May-2011 & $\mathrm{W}-16$ & -11.1 \\
\hline $\mathrm{N}$ & Kurobe, Toyama & 1-May-2011 & -11.4 & -11.7 & 1-May-2011 & $\mathrm{W}-16$ & -11.1 \\
\hline $\mathrm{N}$ & Kurobe, Toyama & 1-May-2011 & -11.9 & -11.7 & 1-May-2011 & $\mathrm{W}-16$ & -11.1 \\
\hline $\mathrm{O}$ & Kurobe, Toyama & 1-May-2011 & -10 & -10.0 & 1-May-2011 & $\mathrm{W}-17$ & -9.4 \\
\hline $\mathrm{P}$ & Iwase, Toyama & 1-May-2011 & -11.5 & -11.5 & 1-May-2011 & $\mathrm{W}-18$ & -9.6 \\
\hline Q & Tonami, Toyama & 30-Apr-2011 & -10.3 & -10.4 & 28-Apr-2011 & W-8 & -9.8 \\
\hline
\end{tabular}

*Collected sake samples bottled at the sake brewery.

**The $\delta^{18} O$ values of nearby groundwater and rivers were estimated from figure 3 of Mizota and Kusakabe (1994) and averaged data from Agata et al. (2001). 


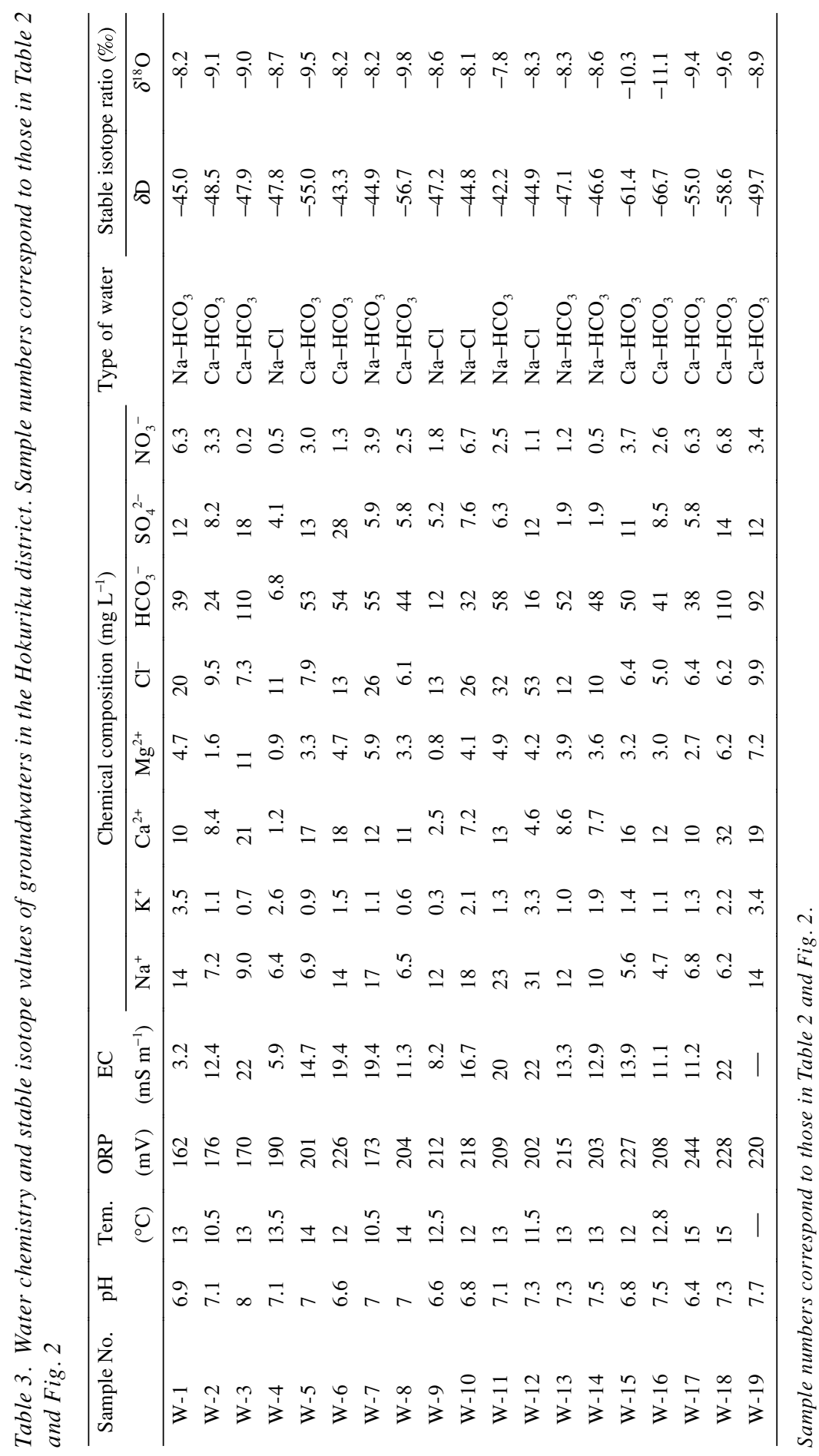




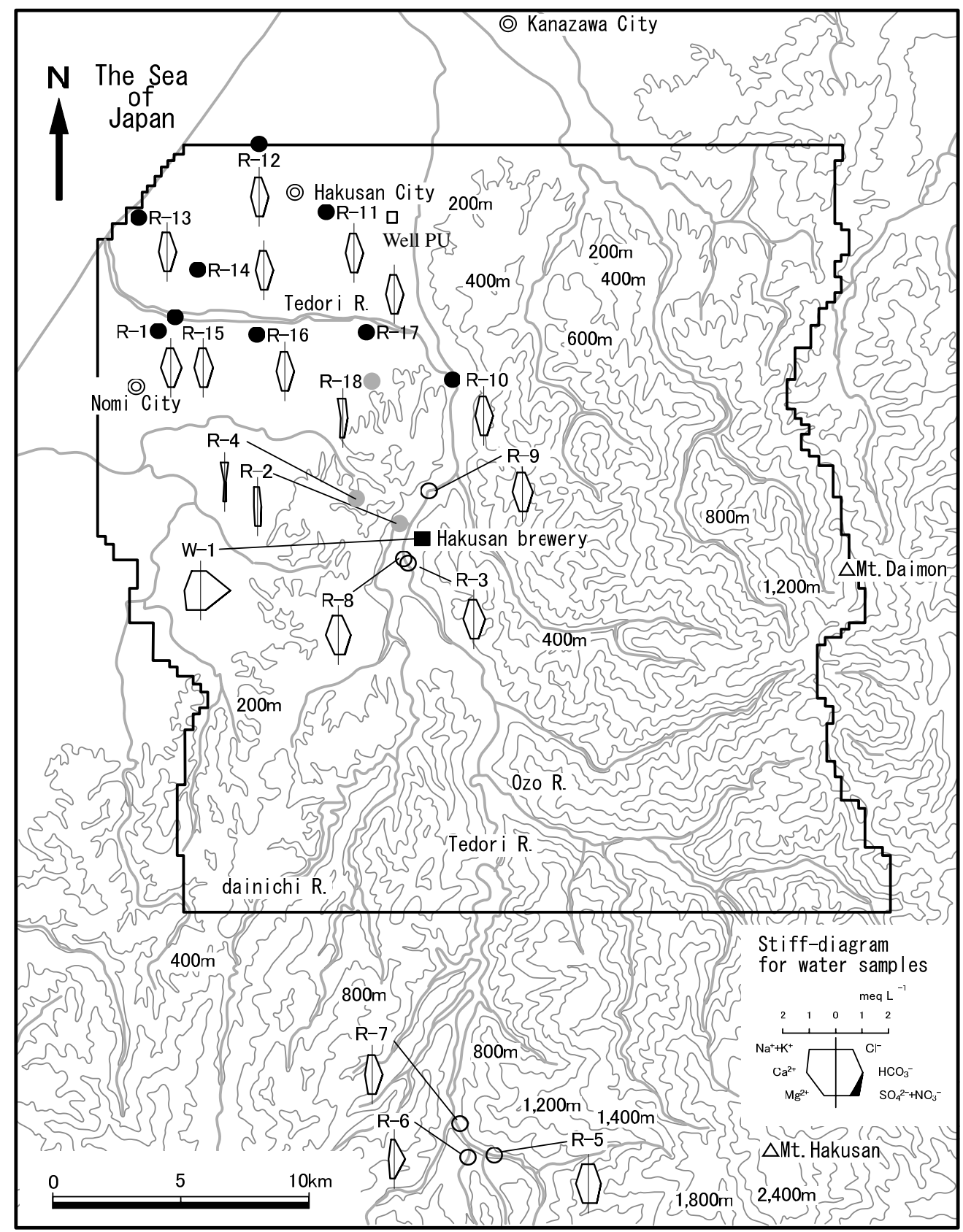

Fig. 3. A detailed map of the study area (Hakusan, Ishikawa Prefecture). Water quality is shown using Stiff-diagrams. The solid lines represent the area covered by the numerical modeling. $\bigcirc$, River water from the alluvial fan area; $\bigcirc$, River water from the talus area; $\bigcirc$, River water from the hill area; $\mathbf{\square}$, Groundwater at Hakusan brewery.

ses were conducted at the Mitsubishi Materials Techno Corporation Analytical Center. The filtered water samples were analyzed for major anions $\left(\mathrm{Cl}^{-}\right.$and $\left.\mathrm{SO}_{4}{ }^{2-}\right)$ with a Dionex ICS-2000 ion chromatograph using an IonPac As22 column. Water samples were filtered in the laboratory 2 or 3 days after collection using a filter which is
$0.22 \mu \mathrm{m}$ size. Alkalinity was determined via a standard $\mathrm{HCl}$ titration. Cations were analyzed using a Dionex DX$320 \mathrm{~J}$ ion chromatograph.

Oxygen isotope ratios were determined by the automated $\mathrm{CO}_{2}$ equilibration method (Epstein and Mayeda, 1953) for both sake and groundwater samples. To ascer- 


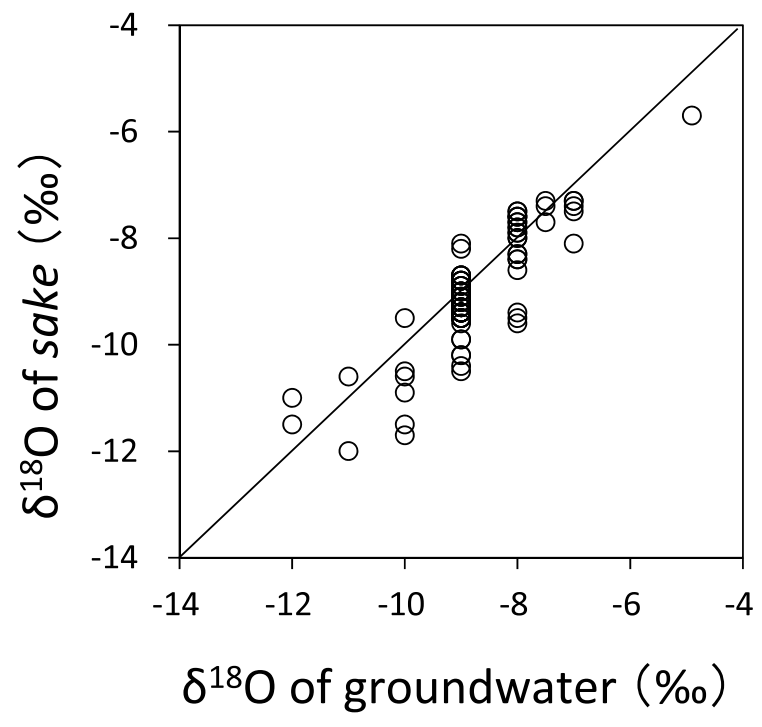

Fig. 4. The observed $\delta^{18} O$ values of sake (this study) vs. shallow groundwaters and river waters in Japan after Mizota and Kusakabe (1994) and Agata et al. (2001). The solid line shows the 1:1 correlation of $\delta^{18} O$ values of water samples.

tain if alcohol content ( $c a .15 \mathrm{wt} \%)$ affects the sake $\delta^{18} \mathrm{O}$, we analyzed $\delta^{18} \mathrm{O}$ values of distilled water containing 0 , $5,10,15$, and $20 \mathrm{wt} \%$ of reagent ethanol. The average $\delta^{18} \mathrm{O}$ values of triple analyses of each sample increased slightly from $-12.15 \pm 0.05 \%$ at $0 \mathrm{wt} \%$ ethanol to -11.94 $\pm 0.03 \%$ at $20 \mathrm{wt} \%$ ethanol. This indicates that alcohol content could influence sake $\delta^{18} \mathrm{O}$ by up to $\sim 0.2 \%$. Given the large isotopic variation between the samples, we did not consider this important, and did not correct for this in our analyses.

The hydrogen isotope ratios of groundwater samples were determined via the $\mathrm{Zn}$ reduction method (Coleman et al., 1982). The $\delta^{18} \mathrm{O}$ and $\delta \mathrm{D}$ were measured with a mass spectrometer (Optima, VG Micromass Co. Ltd.) and reported relative to V-SMOW2 with an analytical precision of $0.1 \%$ for $\delta^{18} \mathrm{O}$ and $1 \%$ for $\delta \mathrm{D}$.

\section{RESULTS AND DISCUSSION}

$\delta^{18} O$ values of sake in Japan

The $\delta^{18} \mathrm{O}$ values of 96 sake samples varied from -12.0 to $-5.7 \%$ and showed a regional pattern of low values in northern Japan and high values in southern Japan, reflecting the latitude effect (Table 1). The $\delta^{18} \mathrm{O}$ values of groundwater supplied to individual sake breweries were estimated from values reported by Mizota and Kusakabe (1994). In Okinawa Prefecture, southern Japan, for which Mizota and Kusakabe (1994) did not report any data, we used an average of the $\delta^{18} \mathrm{O}$ values of 3 spring waters near the sake brewery given in Agata et al. (2001) (Table (a)

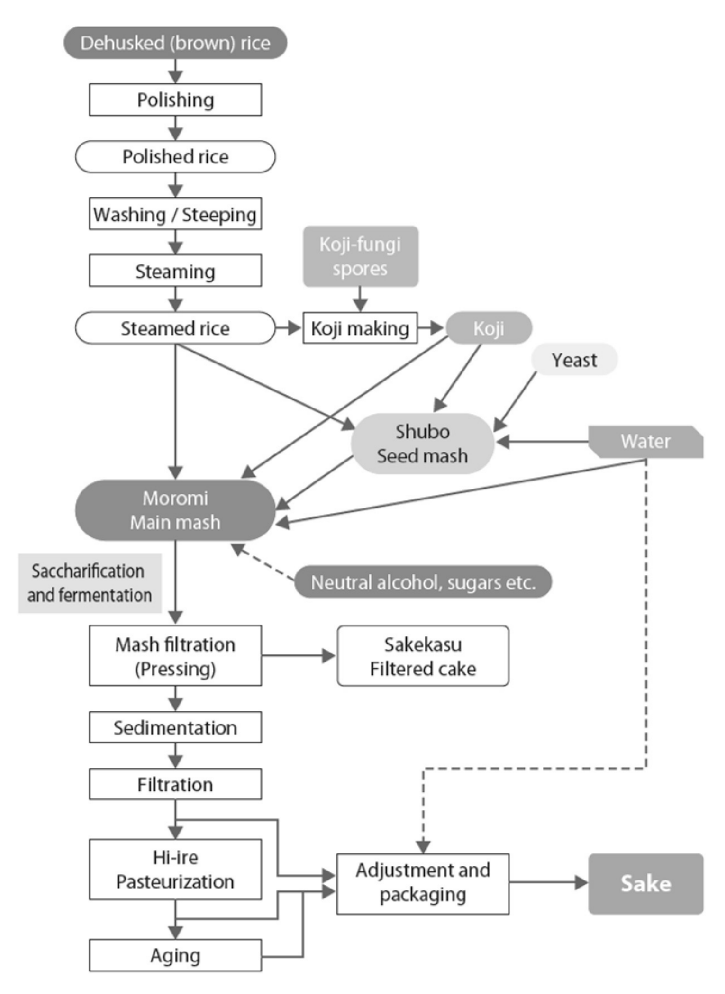

(b)

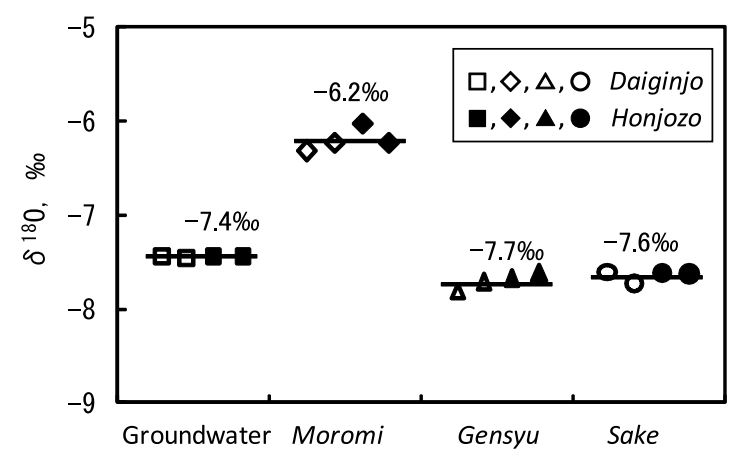

Fig. 5. (a) Outline of sake brewing procedures. (http:// www.japansake.or.jp/sakelenglish/pdf/no_2.pdf). (b) $\delta^{18} O$ of sake during brewing process (Hashiguchi et al., 2011). Open and closed symbols correspond to water samples during sake brewing of two Daiginjo and two Honjozo sakes, respectively.

1). Figure 4 shows a good correlation between the $\delta^{18} \mathrm{O}$ values of sake and the reported $\delta^{18} \mathrm{O}$ of surface and shallow groundwaters. These results indicate that there is no large isotopic fractionation between sake and the shallow groundwater that is used for its production.

The outline of sake-brewing process is shown in Fig. 5a. Non-sticky japonica rice (a short-grained variety of rice) is suitable for sake brewing. Many types of premium 
Table 4. $\delta^{18} \mathrm{O}$ values of sake throughout the various brewing stages

\begin{tabular}{lcccc}
\hline Brewing stages of sake & \multicolumn{4}{c}{$\delta^{18} \mathrm{O}$ of sake (\%o) } \\
\cline { 2 - 5 } & Number of samples & Maximum & Minimum & Average \\
\hline Groundwater & 4 & -7.4 & -7.4 & -7.4 \\
Moromi & 4 & -6 & -6.3 & -6.2 \\
Gensyu & 4 & -7.6 & -7.8 & -7.7 \\
Sake & 4 & -7.6 & -7.7 & -7.6 \\
\hline
\end{tabular}

sake are made from this rice. Since the outer layers of unpolished rice contain large amounts of fats, minerals, and proteins that spoil the flavor of sake, the rice is polished to remove the outer layer using a high speed mill. Normally, the outer $30 \%$ of the grain is removed, leaving the central $70 \%$. For ginjo-shu, the outer $40 \%$ or more of the grain may be removed. After milling, the polished rice is washed in water to remove the bran and is soaked in water. When the grain has absorbed an amount of water equivalent to $30 \%$ of its weight, it is removed from the water and steamed for one hour.

Following this, it is necessary to use enzymes to break down the starch in the rice and to convert it to sugar (yeast fermentation). The enzymes play a number of roles, finely shredding the starch to convert it into sugar, breaking down proteins, and producing peptides and amino acids. For making sake, a substance called kome-koji (koji rice) is used. The koji rice is made by cultivating koji-fungi on steamed rice. The koji-fungus (Aspergillus oryzae) is a beneficial and safe variety of mold. In about two days, the steamed rice is entirely covered with koji-fungi. As the koji-fungi grow, they produce enzymes, which accumulate in the koji.

The standard weight ratio of steamed rice, $k o j i$, and water placed in the fermentation tank is $1: 0.25: 1.63$. In the sake moromi (main mash), the enzymes in koji decompose the steamed rice while the yeast simultaneously ferments the resulting sugars in a single tank. The fermentation temperature is usually in the range of $8-18^{\circ} \mathrm{C}$. The fermentation process takes 3-4 weeks, yielding an alcohol content of $17-20 \%$. When the fermentation is complete, the moromi is passed through a cloth filter and the un-decomposed rice and yeast are removed, leaving new sake. This process may be done by placing the moromi in a cloth bag. A machine is used to apply pressure to the bag from above. Pressure may also be applied horizontally, similar to a beer mash filter press. The cake left over from the process is called sakekasu (filtered sake cake). Some turbidity remains after this filtration process. The liquid is left to stand at low temperature until particles precipitate as sediment. The clear supernatant is transferred into another tank and then filtered to produce a clear liquid. After sedimentation and filtering, most sake undergoes pasteurization (hi-ire) at a temperature of $60-65^{\circ} \mathrm{C}$ before storing. The purpose of pasteurization is to sterilize the liquid, and at the same time render any enzymes inactive. The heating of sake during the pasteurization process alters the aroma and leaves it with an unrefined taste. For this reason, it is allowed to age for six months to one year. The alcoholic content of sake aged in tanks is $17-20 \%$, the same as at the mash filtration stage. As this level is too high for consumption with meals, brewers often add water to reduce the alcohol level to around $15 \%$ before bottling. They may also filter and pasteurize it again, if necessary.

Table 4 and Fig. $5 \mathrm{~b}$ show the $\delta^{18} \mathrm{O}$ values of moromi and two types of sake (genshu and sake) and groundwater used for sake brewing (Hashiguchi et al., 2011). Genshu is the sake obtained after moromi filtration but prior to the addition of water to adjust the alcohol content. The average $\delta^{18} \mathrm{O}$ value of water in moromi is $1.2 \%$ o higher than that of the corresponding groundwater, whereas the values of genshu and sake are very similar to those of groundwater. This means that isotopic fractionation occurs in the water during the production of moromi but there is no significant difference between the groundwater and sake $\delta^{18} \mathrm{O}$ after the removal of moromi. This result is in accord with the fact that there is no significant difference between the $\delta^{18} \mathrm{O}$ of sake and the local shallow groundwater and river water as shown in Fig. 4.

Suzuki et al. (2009) demonstrated that the $\delta^{18} \mathrm{O}$ values of Japanese rice vary from $+25.1 \pm 0.6 \%$ at Okinawa (southern Japan) to $+19.7 \pm 0.5 \%$ at Hokkaido (northern Japan). They generally correlate to the $\delta^{18} \mathrm{O}$ values of local surface waters in the same province, with isotopic fractionation between the rice and water of $\sim 30 \%$. This large fractionation might be due to absorption of local surface water into plant cells and change of the water structure.

During the brewing of sake, the rice absorbs groundwater at room temperature and water content increases from a few $\%$ to $\sim 30 \%$. Then, the rice is steamed and mixed with groundwater in the ratio of 1.63:1 as described above. During the fermentation process, the $\delta^{18} \mathrm{O}$ of the moromi increases to become $1.2 \%$ greater than that of the groundwater (Fig. 5b). The reason for this enrichment 


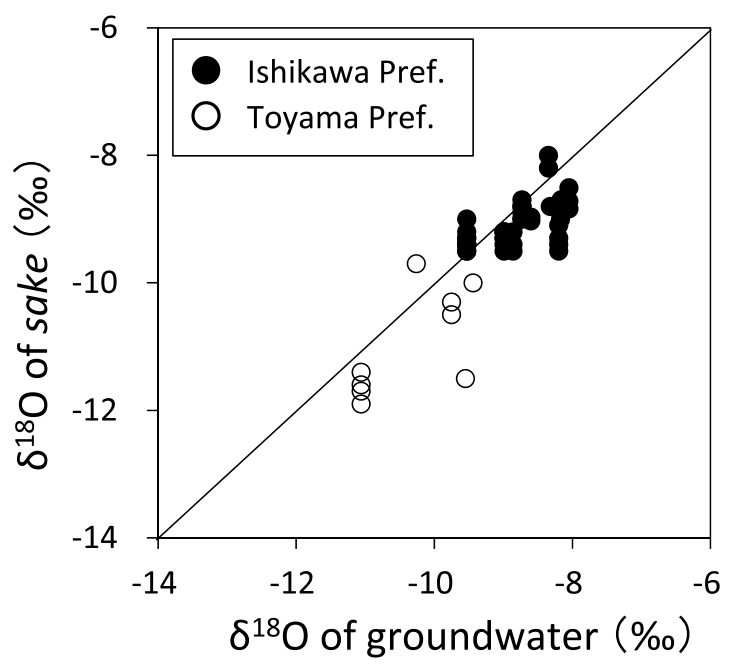

Fig. 6. Observed $\delta^{18} O$ values of sake and groundwaters in the Ishikawa Prefecture (solid circles) and Toyama Prefecture (open circles) of the Hokuriku district. The solid line shows the 1:1 correlation between $\delta^{18} \mathrm{O}$ values of water samples.

of ${ }^{18} \mathrm{O}$ in the moromi cannot be explained presently. It is possible that oxygen molecules in the moromi might be exchanged with oxygen isotopes in $\mathrm{CO}_{2}$. In this study, the $\delta^{18} \mathrm{O}$ values of water in samples were determined with the $\mathrm{CO}_{2}$-water equilibration method without distillation of water from sake. We observed only a slight isotopic difference (up to $\sim 0.2 \%$ ) between distilled waters and those mixed with alcohol (5-20 wt $\%$ ) and concluded that there is no large effect on the $\delta^{18} \mathrm{O}$ values of sake resulting from the presence of alcohol. After formation of moromi, genshu is obtained by filtration, where more than $75 \%$ in volume is water and the remaining $25 \%$ is mainly alcohol. Then, groundwater is added to adjust the alcohol content to form sake. The $\delta^{18} \mathrm{O}$ of the sake returns to a value similar to that of the groundwater during these processes.

$\delta^{18} \mathrm{O}$ values of sake and groundwater in the Hokuriku district

Figure 6 plots the $\delta^{18} \mathrm{O}$ values of sake from the Hokuriku district against those of local groundwaters. There is no significant difference between the sake and groundwater $\delta^{18} \mathrm{O}$ values. It is noted that the $\delta^{18} \mathrm{O}$ values in the Ishikawa Prefecture are higher than those in Toyama. Figure 7 shows the relationship between the $\delta \mathrm{D}$ and $\delta^{18} \mathrm{O}$ values of shallow groundwaters. A plot of all the data along a local meteoric water line defined as $\delta \mathrm{D}$ $=8 \delta^{18} \mathrm{O}+21.1$. Mizota and Kusakabe (1994) reported low $\delta \mathrm{D}$ and $\delta^{18} \mathrm{O}$ values in the mountain districts of central Japan $(>3,000 \mathrm{~m})$. The low $\delta^{18} \mathrm{O}$ values of the Toyama groundwater indicate a high mountain origin for this water.

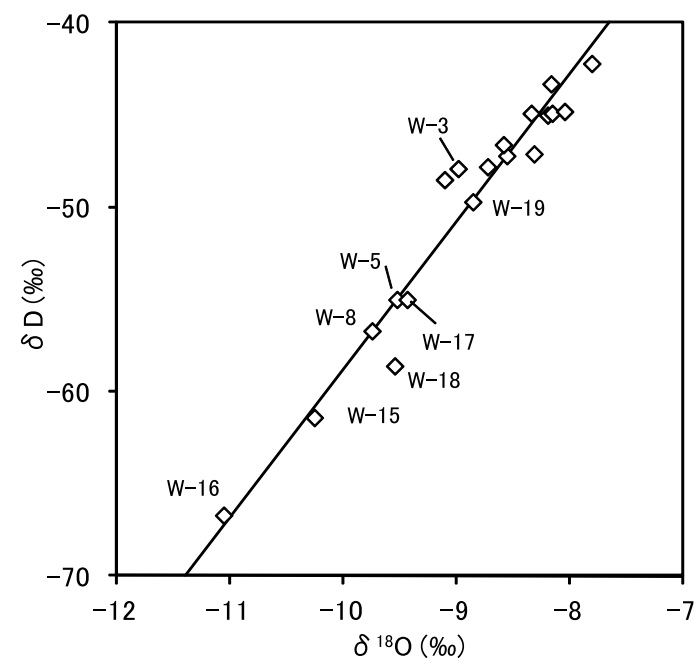

Fig. 7. Relationship between $\delta D$ and $\delta^{18} O$ of groundwaters in the Hokuriku district. Solid line shows the local meteoric water lines in this region $\left(\delta D=8 \delta^{18} O+21.2\right)$.

$\delta D$ and $\delta^{18} O$ values of water samples in the Hakusan area

There are 20 sake breweries in the southern Ishikawa prefecture. Many of them including the sake "Hakusan" are located in the Tedori alluvial fan. In order to know the source and the mode of groundwater flow that supplies water to the "Hakusan" brewery, sake samples from four breweries were analyzed. The $\delta^{18} \mathrm{O}$ values of water in the sake samples are shown in Table 5. The sake breweries produce two types of sake (daiginjo and honjozo), which differ in their quality. $\delta^{18} \mathrm{O}$ values are almost constant (within $\pm 0.3 \%$ ) in individual sake breweries (Table $5)$.

The $\delta \mathrm{D}$ and $\delta^{18} \mathrm{O}$ values of river water from the alluvial fan are -44.7 to $-71.2 \%$ and -8.4 to $-11.1 \%$, respectively, (Table 6 and Fig. 8). Most samples plot along the meteoric water line with $d=18.5$ in the study area (Fig. 8). A clear difference is observed in the isotopic compositions of the three groups of river waters. The hill area river waters have lower isotopic ratios than the other areas, with $\delta \mathrm{D}$ of -62.9 to $-71.2 \%$ and $\delta^{18} \mathrm{O}$ of 9.9 to $-11.1 \%$ (Table 6). There is no clear difference in the $\delta \mathrm{D}$ and $\delta^{18} \mathrm{O}$ values between river water samples from the southern (R-5, R-6, and R-7) and northern (R-3, R-8, and R-9) parts of the study area (Fig. 9). The river water samples from the talus area have higher $\delta \mathrm{D}(-53.8$ to $-44.5 \%)$ and $\delta^{18} \mathrm{O}$ values $(-9.0$ to $-8.4 \%$ ) than those from the alluvial fan area, where $\delta \mathrm{D}$ ranges between -61.5 and $-56.5 \%$ and $\delta^{18} \mathrm{O}$ between -10.0 and $-9.4 \%$ (Table 6 ).

Figure 9 shows the distribution of $\delta^{18} \mathrm{O}$ values of all samples in this study area. There is a tendency of increasing $\delta^{18} \mathrm{O}$ from mountainous regions to coastal sites. The $\delta \mathrm{D}$ and $\delta^{18} \mathrm{O}$ values of the Tedori River, a major river in 
Table 5. $\delta^{18} \mathrm{O}$ values of sake from 4 breweries in the Hakusan City study area

\begin{tabular}{lccccc}
\hline \multirow{2}{*}{ Sake brewery } & \multicolumn{3}{c}{$\delta^{18} \mathrm{O}$ of sake (\%o) } & \multirow{2}{*}{$\delta^{18} \mathrm{O}$ of groundwater (\%o) } \\
\cline { 2 - 4 } & Number of samples & Maximum & Minimum & Average & \\
\hline A & 5 & -9.2 & -9.5 & -9.3 & -9.0 \\
B & 5 & -9.2 & -9.5 & -9.4 & -9.5 \\
C & 5 & -9.0 & -9.5 & -9.3 & -9.5 \\
D & 5 & -8.7 & -9.0 & -8.9 & -8.7 \\
\hline
\end{tabular}

this area, increase from $-71.2 \%$ and $-11.1 \%$ at $\mathrm{R}-5$, the most upstream sample to $-58.1 \%$ and $-9.7 \%$ at R-15, the most downstream sample, respectively (Fig. 9). Stable isotopic compositions of groundwater and river waters in the Ishikawa prefecture have been previously reported (e.g., Mizota and Kusakabe, 1994; Tomita et al., 2004; Tsuchihara et al., 2011). From these results, the $\delta \mathrm{D}$ and $\delta^{18} \mathrm{O}$ of river waters vary from -80 to $-60 \%$ and -12 to $-9 \%$, respectively, similar to those obtained in this study. Tsuchihara et al. (2011) found an altitude effect as shown by the following equation:

$$
\delta^{18} \mathrm{O}=-0.0022 h-8.0\left(R^{2}=0.71\right)
$$

where $h$ is the altitude of the river water sample site. The change in the $\delta \mathrm{D}$ and $\delta^{18} \mathrm{O}$ in the Tedori River from upstream to downstream might reflect an altitude effect (Dansgaard, 1964; Waseda and Nakai, 1983).

Two groundwater samples collected on different days at the same location have almost identical values $(-47.9$ and $-50.2 \%$ for $\delta \mathrm{D}$ and -9.0 and $-8.8 \%$ or or $\delta^{18} \mathrm{O}$ ). These values are similar to those of river water from the talus area collected at $200-500 \mathrm{~m}$ in altitude, higher than the other river waters. From Eq. (1), the groundwater (W-1 and $\mathrm{W}-2$ ) is considered to have originated at an altitude of $360-450 \mathrm{~m}$. These results may imply that the groundwaters at the sake brewery might come from river waters that infiltrated into the talus area. Tsuchihara et al. (2011) examined the seasonal variation in $\delta^{18} \mathrm{O}$ values of shallow and deep groundwaters in a well (well PU, Fig. 3) in the central part of the alluvial area $(40 \mathrm{~m}$ in altitude, close to the R-11 sampling site) over a 2-year period (July 2008 to July 2010). They reported an increase in $\delta^{18} \mathrm{O}$ values of the shallow groundwater from -8.5 to $-7.5 \%$ with increases in groundwater levels and precipitation. In contrast, the $\delta^{18} \mathrm{O}$ of deep groundwater showed little variation and remained almost constant at $-9.4 \pm$ $0.2 \%$. These values are similar to those observed of groundwaters at the sake brewery in this study but higher than that of R-11 river water sample ( $-9.9 \%$; Table 6$)$. Tsuchihara et al. (2011) demonstrated that $\mathrm{Cl}$ concentration of shallow groundwaters decreased from 17 to $6 \mathrm{mg} /$ $\mathrm{L}$ with increasing infiltration of river water. This was es-

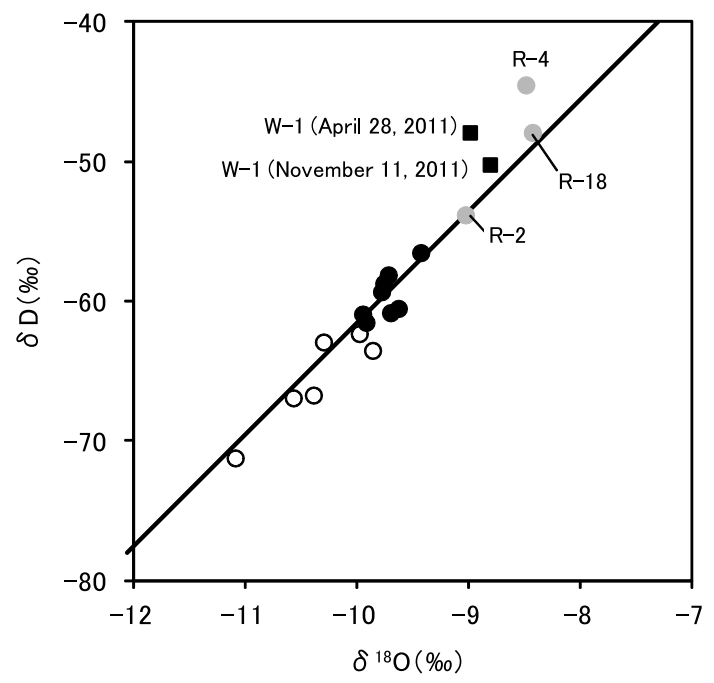

Fig. 8. Relationship between $\delta D$ and $\delta^{18} O$ of groundwaters in the Hakusan area. Solid line shows the meteoric water line in this region $\left(\delta D=8 \delta^{18} O+18.5\right)$. River water from the alluvial fan area; $\bigcirc$, River water from the talus area; $\bigcirc$, River water from the hill area; $\mathbf{\square}$, Groundwater.

timated using an end-members mixing analysis (Hooper et al., 1990; Ladouche and Weng, 2005). In our study, two groundwater samples show $\mathrm{Cl}$ concentrations of 7.3 and $15 \mathrm{mg} / \mathrm{L}$ and $\delta^{18} \mathrm{O}$ of -8.8 and $-9.0 \%$. These chemical and isotopic differences may reflect a different river water infiltration ratio.

Chemical compositions of water samples in the Hakusan area

The chemical and isotopic compositions of groundwater (W-1) and river water (R-1 to R-18) are shown in Table 6 and Figs. 10 and 11. All samples are weakly alkaline $(\mathrm{pH}=7.1$ to 8.8$)$. The river water samples are characterized by lower EC values $(5-20 \mathrm{mS} / \mathrm{m})$ than those of groundwater (22 and $27 \mathrm{mS} / \mathrm{m}$ ) in the study area. In particular, samples from the talus area (R-2, R-4, and R-18) have lower EC values $(5.0-8.1 \mathrm{mS} / \mathrm{m})$ than the other river waters (Table 6).

The groundwater used for the sake production is taken 


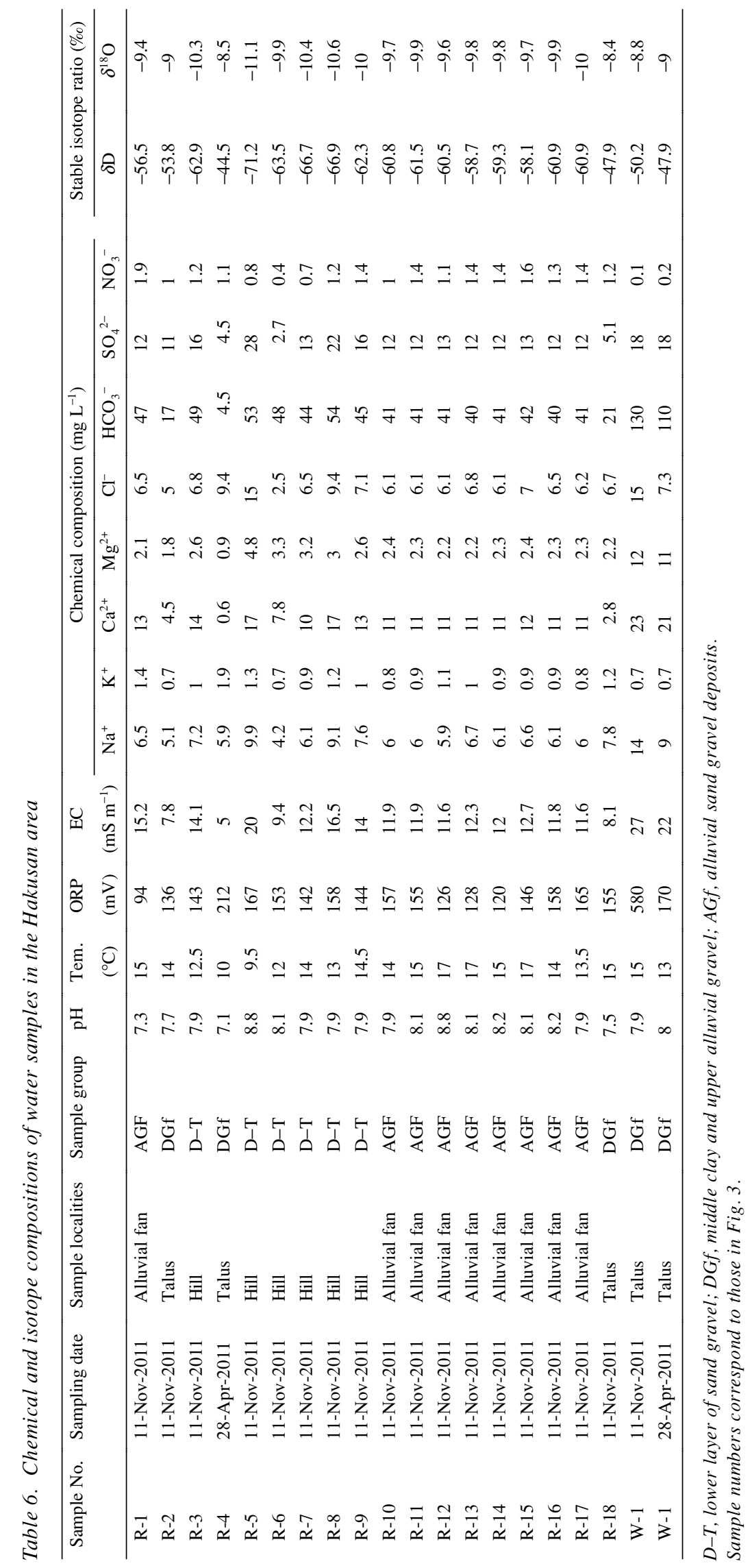




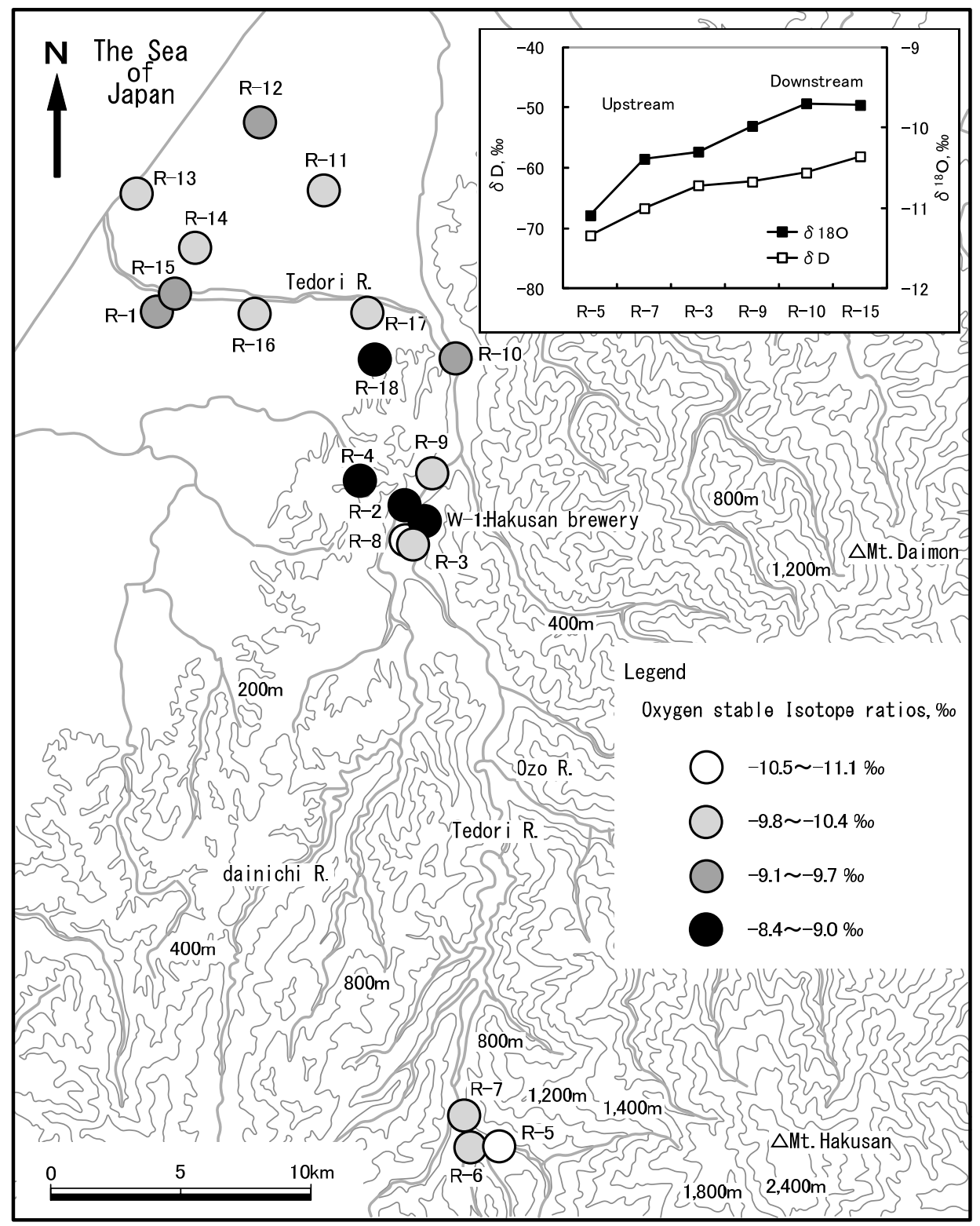

Fig. 9. Spatial distribution of $\delta^{18} O$ values of water samples in the Hakusan area. Inset shows the $\delta D(\square)$ and $\delta^{18} O$ values of the Tedori river waters.

from a depth of $100 \mathrm{~m}$. Samples from this depth were collected in April and November, 2011. The April sample was slightly lower in $\mathrm{Na}^{+}, \mathrm{Cl}^{-}$, and $\mathrm{HCO}_{3}^{-}$than the November sample. This result suggests little seasonal variation in chemical composition of groundwater at this location. Figure 10 shows that river waters from the alluvium fan and hill areas are almost identical, with chemical compositions of $\mathrm{Ca}^{2+}-\mathrm{HCO}_{3}{ }^{-}$type. In contrast, the river waters from the talus area, $\mathrm{R}-2, \mathrm{R}-4$, and $\mathrm{R}-18$ are of $\mathrm{Na}^{+}-\mathrm{Ca}^{2+}-\mathrm{HCO}_{3}^{-}, \mathrm{Na}^{+}-\mathrm{Cl}^{-}$, and $\mathrm{Na}^{+}-\mathrm{HCO}_{3}^{-}$types, respectively. Tsuchihara et al. (2011) reported chemical compositions of shallow and deep groundwaters in the Tedori alluvial fan that were similar to those of this study. The deep groundwaters in the southern part of the Tedori River reported by Tsuchihara et al. (2011) have the same chemical compositions as river waters from the talus area in this study. In contrast, the shallow groundwaters in the southern part of the Tedori River were enriched in $\mathrm{Na}^{+}$, $\mathrm{K}^{+}$, and $\mathrm{HCO}_{3}{ }^{-}$. These results imply that deep groundwaters in the southern part of the Tedori River 


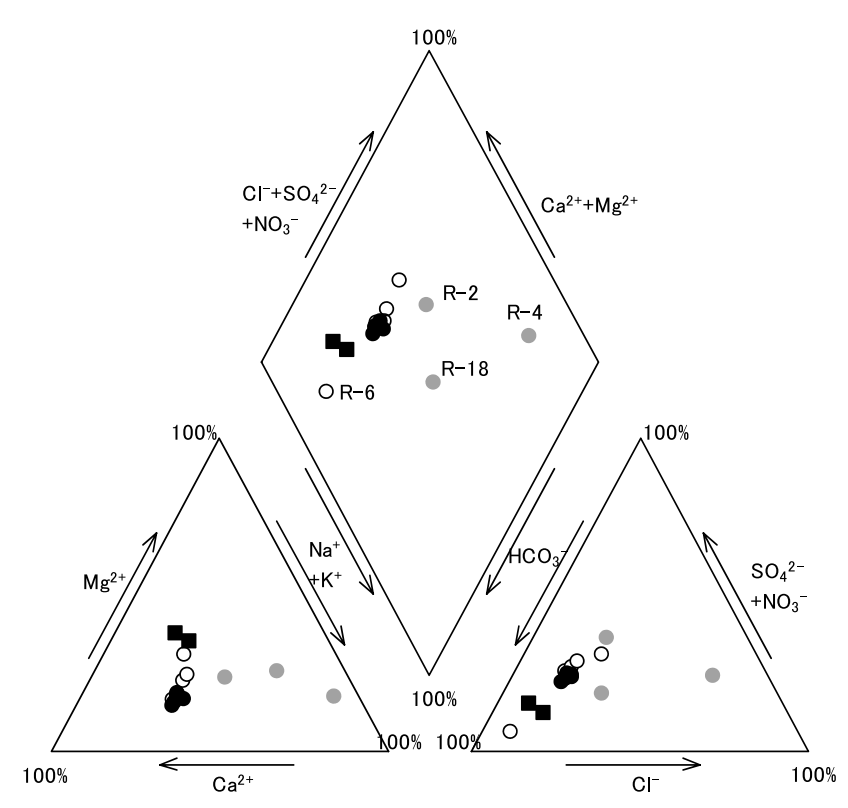

Fig. 10. Trilinear diagrams for the water samples in Hakusan area. River water from the alluvial fan area; $\bigcirc$, River water from the talus area; $\bigcirc$, River water from the hill area; Groundwater.

derive from river waters that infiltrate at the talus area.

The $\mathrm{Ca}^{2+}$ and $\left(\mathrm{Ca}^{2+}+\mathrm{Mg}^{2+}\right)$ concentrations of water samples increase with increasing $\mathrm{HCO}_{3}$ as shown in Fig. 11, where the dotted lines correspond to calcite and dolomite dissolution lines. From the chemical compositions of groundwater samples, the saturation indices (S.I.) of calcite $\left(\mathrm{CaCO}_{3}\right)$ and dolomite $\left(\mathrm{CaMg}\left(\mathrm{CO}_{3}\right)\right)$ were calculated using the following equation:

$$
\text { S.I. }=\log (Q / K) \text {, }
$$

where $Q$ and $K$ are the mineral's (calcite i.e., $\left(\mathrm{Ca}^{2+}\right)$ $\left.\left(\mathrm{CO}_{3}^{2-}\right)\right)$ activity and solubility products, respectively. If S.I. $>0$, the fluid is saturated with respect to a mineral, that mineral would be precipitated. The chemical code PHREEQC (Parkhurst and Appelo, 1999) was used in this study. The S.I. values obtained for the groundwater samples collected in April and November, 2011 were the same: -0.15 for calcite and -0.37 and for dolomite. Enrichment of $\mathrm{Ca}^{2+}$ and $\mathrm{HCO}_{3}{ }^{-}$is due to dissolution of carbonate minerals such as calcite and dolomite. The hydrolysis and dissolution reactions of limestone and dolomite to form dissolved bicarbonate, calcium, and magnesium ions can be described following Appelo and Postma, 2005:

$\mathrm{CaCO}_{3}+\mathrm{H}_{2} \mathrm{O}=\mathrm{Ca}^{2+}+\mathrm{HCO}_{3}^{-}+\mathrm{OH}^{-}$

$\mathrm{CaMg}\left(\mathrm{CO}_{3}\right)+2 \mathrm{H}_{2} \mathrm{O}=\mathrm{Ca}^{2+}+\mathrm{Mg}^{2+}+2 \mathrm{HCO}_{3}^{-}+2 \mathrm{OH}^{-}$ (a)

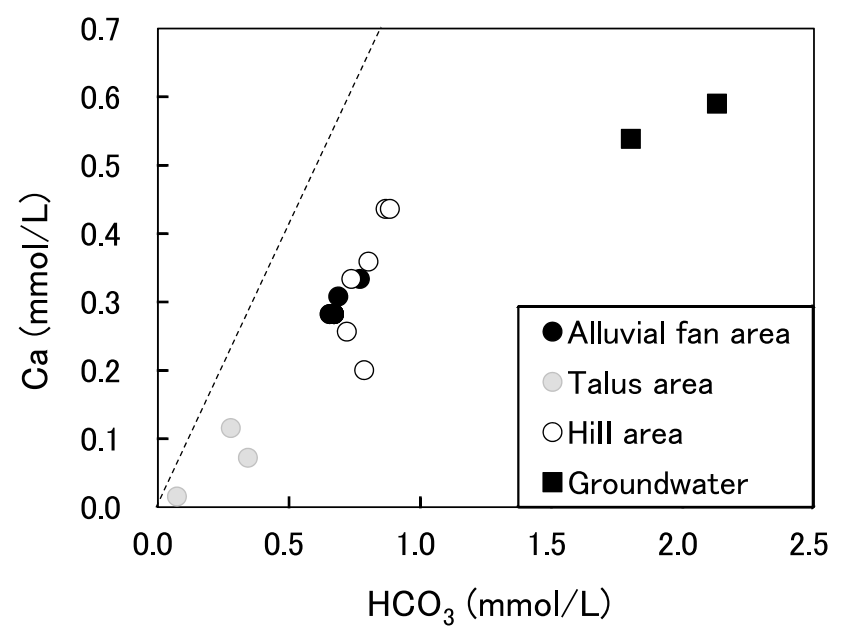

(b)

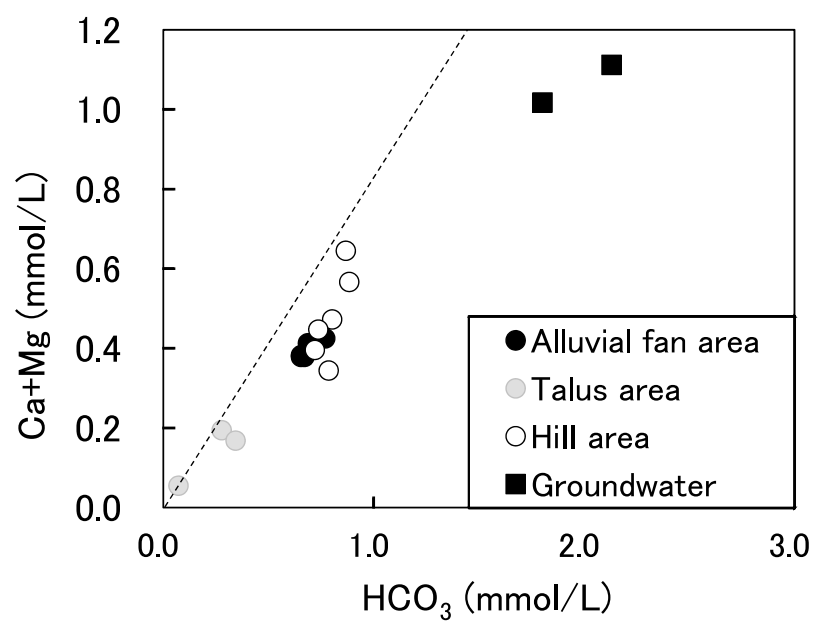

Fig. 11. Relationship between $\mathrm{Ca}$ and $\mathrm{HCO}_{3}(\mathrm{a})$, and $\mathrm{Ca}+\mathrm{Mg}$ and $\mathrm{HCO}_{3}(b)$ of groundwaters in the Hakusan area. The broken lines indicate stoichometric dissolution of calcite (a) and dolomite (b). O, River water from the alluvial fan area; River water from the talus area; $\bigcirc$, River water from the hill area; $\mathbf{\square}$, Groundwater.

$\mathrm{CO}_{2}+\mathrm{H}_{2} \mathrm{O}=\mathrm{HCO}_{3}^{-}+\mathrm{H}^{+}$

$\mathrm{Ca}^{2+}$ and $\mathrm{Mg}^{2+}$ in the groundwaters within alluvial fans throughout the world have shown a good correlation. These components are considered to come from dissolution of carbonate minerals (e.g., Hidalgo and CruzSanjulian, 2001; Chkirbene et al., 2009). Carbonate rocks are commonly observed at the location of the sake brewery in the Tedori fan (Obara, 1961). These rocks are a likely source of groundwater $\mathrm{Ca}^{2+}$ and $\mathrm{Mg}^{2+}$. 


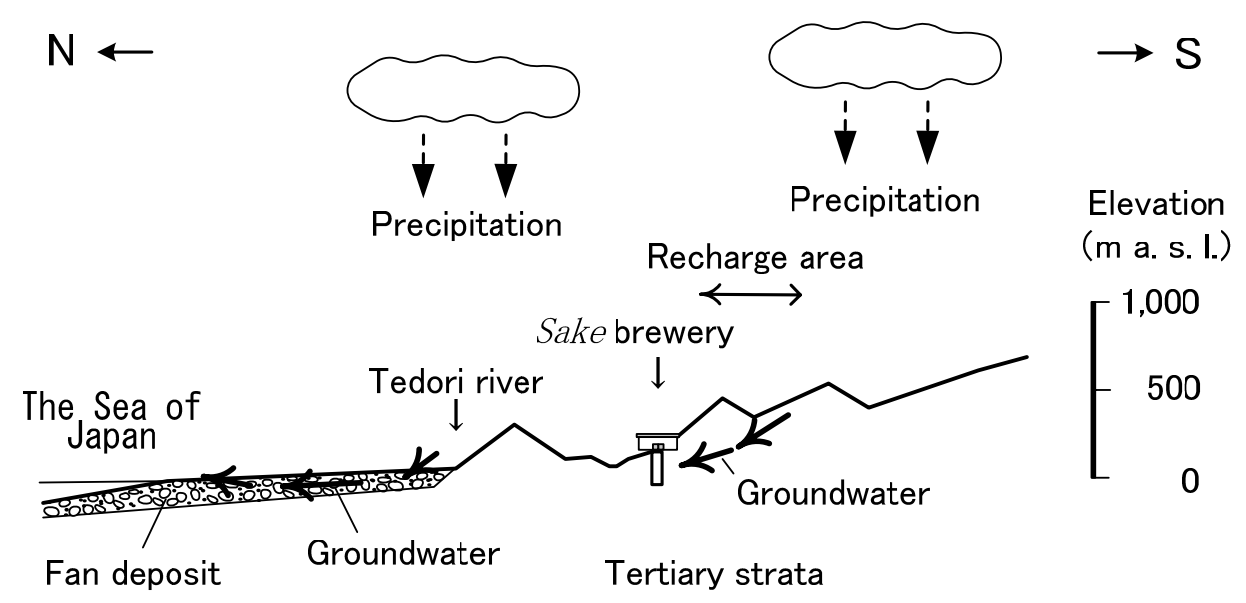

Fig. 12. Schematic vertical section showing flow direction and recharge of river water and groundwater in the Hakusan area.

\section{Modeling of groundwater movement}

Figure 12 shows a schematic model showing flow direction and discharge of groundwater. The $\delta^{18} \mathrm{O}$ and $\delta \mathrm{D}$ values of two groundwaters are similar to those of river water from the talus area collected at $200-500 \mathrm{~m}$ altitude. A three-dimensional numerical groundwater flow model was used to estimate the flow of groundwater at a particular sake brewery. Table 7 shows the conditions used for the numerical model. The modeling area covers 30 $\mathrm{km} \times 30 \mathrm{~km} \times 2 \mathrm{~km}$ (Fig. 13a). The surface geometry was reproduced from a digital elevation model (DEM) and pasted on a numerical model of the ground surface. The DEM data was taken from "Digital Map $50 \mathrm{~m}$ Grid (Elevation)" of the Geographical Survey Institute. The hydrogeological parameters used in the model are given in Table 7 for the fan deposit, Neogene sediment, Tedori Formation, and Pre-Neogene granitic rocks. The surface strata, excluding alluvial fan deposits, were treated as weathered layers with high permeability. The surface boundary condition was specified by the recharge rates ranging from 0.21 to $0.86 \mathrm{~mm} /$ day. Zero meter water pressure head was assumed for the coast and rivers. The amount of rainfall in this area was calculated from the annual precipitation (AMeDAS data at Komatsu, Yoshino Hakusan, and Shiramine Hakusan), evaporation rate, and river runoff (Maruyama et al., 2012). The bottom and sides of the model were assumed to be impermeable boundaries. The program code used in this study was Dtransu-3D-EL advection-dispersion analysis, a threedimensional saturated-unsaturated seepage flow calculation code (Hishiya et al., 1999). The pre- and postprocessor software is G-TRAN/3D for Dtransu-3D. The permeability $(k)$ for the numerical analysis area was taken from a database which was collected from literatures about permeability of sediments and rocks in Japan (Umeda $e t$
Table 7. Basic design and physical parameters used in this study for flow simulation

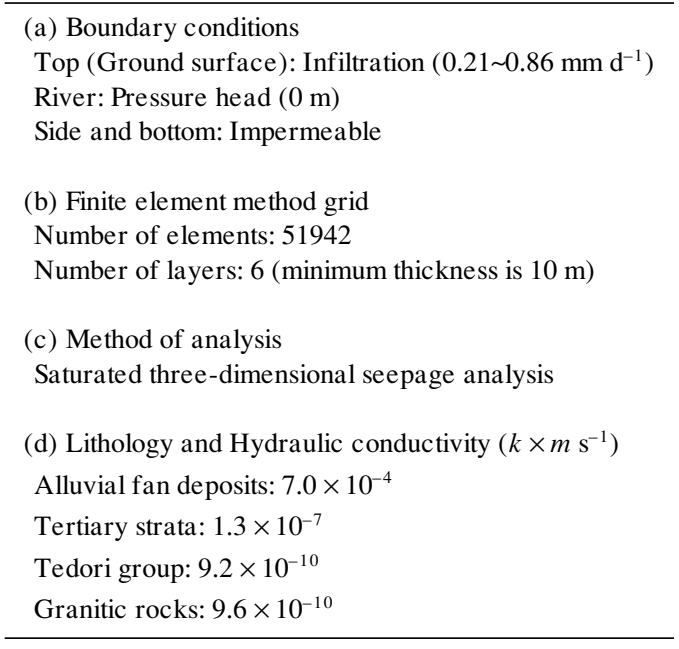

al., 1995).

The distribution of water pressure head in the Tedori alluvial fan is shown in Fig. 13b. The model results match well with observed data, showing that the depth of water table at the end of the fan is shallower than $2 \mathrm{~m}$ (Okuyama, 2010) and increases in depth towards the north. Figure $13 \mathrm{~b}$ also shows that the water table of the alluvial fan is located beneath the ground surface at the end of the fan (Tedori Iseki) and is nearly $18 \mathrm{~m}$ deep in the central fan (Taiheiji). The calculated and measured water tables were $2 \mathrm{~m}$ deep at Tedori Iseki; and the calculated water table was $18 \mathrm{~m}$, and the measured water table $20 \mathrm{~m}$ deep at Taiheiji. The calculated water tables are in close agreement with the observed levels, indicating that the model accurately represents the water flow in the study area. 
(a)

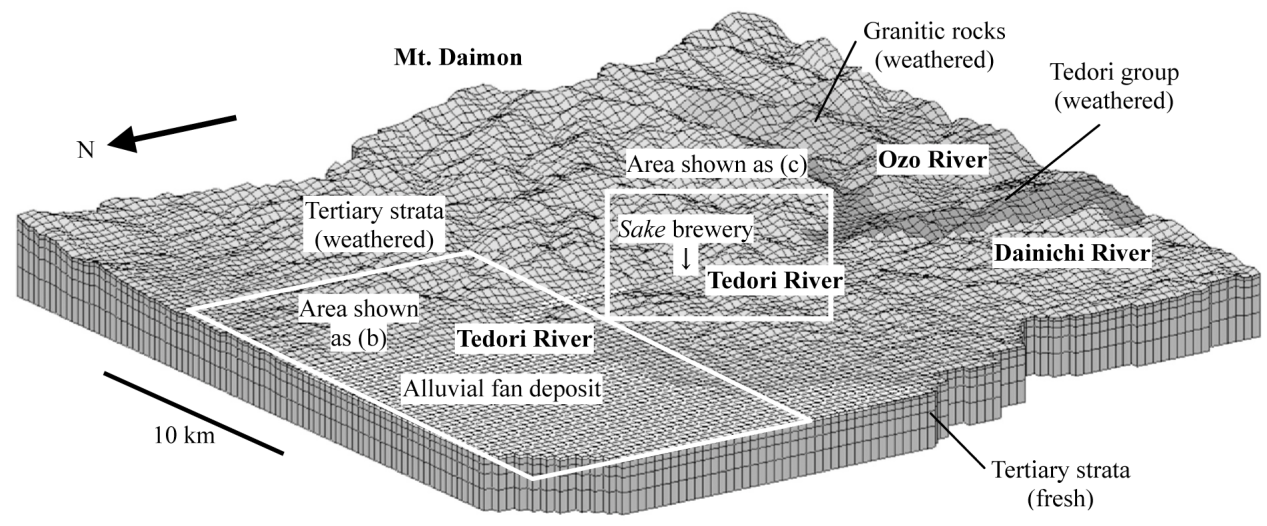

(b)

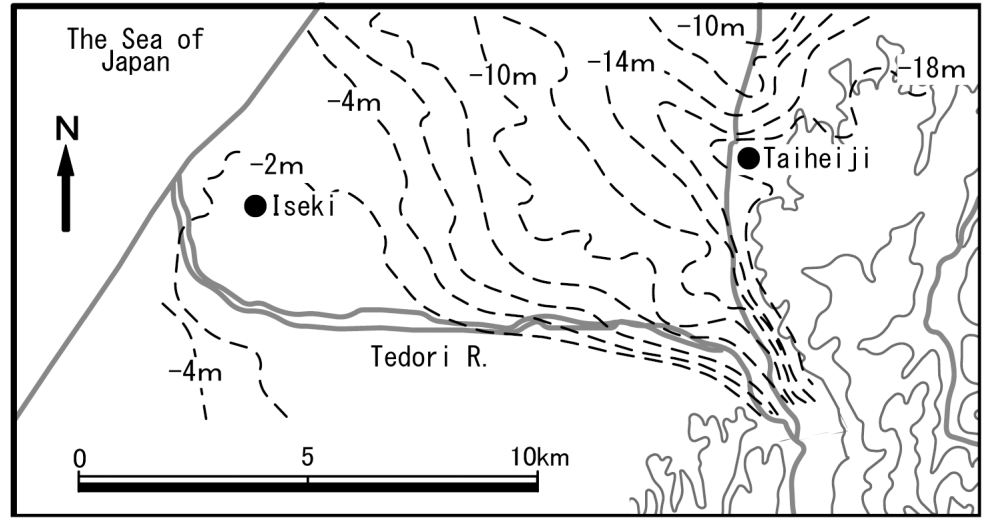

(c)

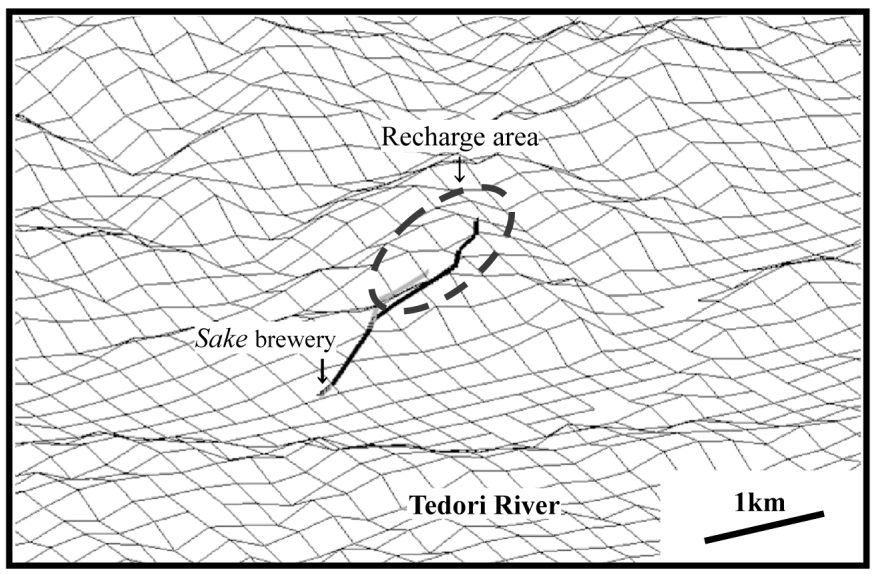

Fig. 13. Three-dimensional simulation of groundwater flow in the Hakusan area. (a) Blocks for simulation of water flow, (b) Distribution of calculated water heads (dashed line) obtained from the flow simulation Two closed circles (Iseki and Taiheiji) indicate groundwater wells. The calculated water heads are close to the observed water heads. (c) Stream lines of groundwater in the lower (black) and upper (gray) aquifer toward the sake brewery. Broken circle indicates the recharge area of groundwater for the sake brewery. The grid lines in (c) show the terrain of the area. 
Figure 13c shows the results of the prediction analysis. Solid lines show the calculated trace lines for the source of groundwater for sake brewing for which recharge occurs at the 440-540 m elevation and has a flow path $2-3 \mathrm{~km}$ long (broken circle in Fig. 13c). The effect of pumping depth in the well on the water source is examined. The Darcy flow rate of groundwater in the calculation was $0.0002-0.015 \mathrm{~m} /$ day. The actual flow rate using the effective porosity of 0.02 is $0.01-0.75 \mathrm{~m} /$ day. Groundwater flow predicted by the above numerical analysis is consistent with the results from stable isotope and water chemistry analyses. These results suggest that the combination of geochemical and numerical modeling techniques provides a useful tool to predict the source of groundwater.

\section{CONCLUSIONS}

"Hakusan," one of the premium brand sakes in Japan, is brewed in Hakusan City, Ishikawa. In this study, the water chemistry and $\delta \mathrm{D}$ and $\delta^{18} \mathrm{O}$ contents of groundwater used in the sake brewing process and the surrounding river waters were analyzed to estimate its source. The results indicate that the groundwater used in the "Hakusan" brewery comes from mountain slopes at $360-450 \mathrm{~m}$ altitude. The 3-D modeled groundwater flow, which is independent of the geochemical method, also supports this view. Our study indicates that simultaneous analyses of numerical and geochemical techniques can help estimate the source and water movement of groundwater used in sake production. The observed $\delta^{18} \mathrm{O}$ of 96 sake samples in 19 provinces in Japan showed a good correlation with that of corresponding groundwater. This indicates that the $\delta^{18} \mathrm{O}$ of sake is a useful parameter to identify the location of sake production, which will help prevent fraudulent representation of the location of sake production.

Acknowledgments - The authors wish to thank to the members of sake brewery in Hakusan City for allowing us to sample groundwaters used for sake production. The authors wish to thank the members of Mitsubishi Materials Techno Corp., especially A. Miyaoka for oxygen isotopic analyses of water samples. N. Okakita is also acknowledged for analyzing oxygen isotope compositions of alcohol containing water samples. C. Mizota, F. Yanagisawa, and M. Kusakabe are acknowledged for their critical comments and for improving the English used in this manuscript.

\section{REFERENCES}

Adamo, P., Zampella, M., Quétel, C. R., Aversano, R., Piaz, F., Tommasi, N., Frusciante, L., Iorizzo, M., Lepore, L. and Carputo, D. (2012) Biological and geochemical markers of the geographical origin and genetic identity of potatoes. $J$. Geochem. Explor. 121, 62-68.
Agata, S., Satake, H. and Tokuyama, A. (2001) Chemical characteristics and isotopic compositions of spring and river waters in Okinawa Island. Chikyukagaku (Geochemistry), 35, 27-41 (in Japanese with English abstract).

Appelo, C. A. J. and Postma, D. (2005) Geochemistry, Groundwater and Pollution. 2nd ed., AA Balkema, Amsterdam, 649 pp.

Brewing Society of Japan (ed.) (1996) Text of the Latest Brewing Technology, $30 \mathrm{pp}$.

Chesson, L. A., Podlesak, D. W., Erkkila, B. R., Cerling, T. E. and Ehleringer, J. R. (2010) Isotopic consequences of consumer food choice: Hydrogen and oxygen stable isotope ratios in foods from fast food restaurants versus supermarkets. Food Chem. 119, 1250-1256.

Chkirbene, A., Tsujimura, M., Charef, A. and Tanaka, T. (2009) Hydro-geochemical evolution of groundwater in an alluvial aquifer: Case of Kurokawa aquifer, Tochigi prefecture, Japan. Desalination 246, 485-495.

Coleman, M. L., Shepherd, T. J., Durham, J. J., Rouse, J. E. and Moore, G. R. (1982) Reduction of water with zinc for H-isotope analysis. Anal. Chem. 54, 993-995.

Crittenden, R. G., Andrew, A. S., LeFournour, M., Young, M. D., Middleton, H. and Stockmann, R. (2007) Determining the geographic origin of milk in Australasia using multielement stable isotope ratio analysis. Int. Dairy J. 17, 421428.

Dansgaard, W. (1964) Stable isotopes in precipitation. Tellus 16, 436-438.

Dion, M. A., Luykx, M. and Saskia, M. R. (2008) An overview of analytical methods for determining the geographical origin of food products. Food Chem. 107, 897-911.

Epstein, S. and Mayeda, T. (1953) Variation of the ${ }^{18} \mathrm{O} /{ }^{16} \mathrm{O}$ ratio in natural waters. Geochim. Cosmochim. Acta 4, 213224.

Hashiguchi, T., Izu, H., Sudo, S., Tomiyama, S., Miyaoka, A., Koizumi, Y. and Kitai, A. (2011) Comparison of oxygen isotopic compositions between sake and the source water. The Fifth Meeting of Discussion Group of Analysis for Labeling Origin, The Japan Society for Analytical Chemistry, Saitama, Japan, P3 (in Japanese).

Hidalgo, M. C. and Cruz-Sanjulian, C. (2001) Groundwater composition, hydrochemical evolution, and mass transfer in a regional detrital aquifer (Baza basin, southern Spain). Appl. Geochem. 16, 745-758.

Hishiya, T., Nishigaki, M. and Hashimoto, N. (1999) The Three Dimensional numerical analysis method for density dependent groundwater flow with mass transport. ProceedingsJapan Society of Civil Engineers 638, 59-69.

Hokuriku Agriculture Report (1977) Hydrogeology and groundwater in Ishikawa Prefecture, Hokuriku Agriculture Report, $58 \mathrm{pp}$.

Hooper, R. P., Christophersen, N. and Peters, N. E. (1990) Modeling streamwater chemistry as a mixture of soilwater end-members - an application to the Panola Mountain catchment, Georgia, U.S.A. J. Hydrol. 116, 321-343.

Kelly, S., Heaton, K. and Hoogewerff, J. (2005) Tracing the geographical origin of food: The application of multielement and multi-isotope analysis. Trends Food Sci. Tech. 16, 555-567. 
Ladouche, B. and Weng, P. (2005) Hydrochemical assessment of the Rochefort marsh: Role of surface and groundwater in the hydrological functioning of the wetland. J. Hydrol. 314, 22-42.

Marisa, C., Almeida, R., Teresa, M. and Vasconcelos, S. D. (2004) Does the winemaking process influence the wine ${ }^{87} \mathrm{Sr} /{ }^{86} \mathrm{Sr}$ ? A case study. Food Chem. 85, 7-12.

Maruyama, T., Noto, F., Yoshida, T., Nakamura, K., Horino, H., Murashima, K. and Takimoto, H. (2012) Analysis of water balance at the Tedori River alluvial fan areas in Japan. J. Japan Coc. Hydrol. and Water Resour. 25, 20-29 (in Japanese with English abstract).

Mizota, C. and Kusakabe, M. (1994) Spatial distribution of $\delta$ D$\delta^{18} \mathrm{O}$ values of surface and shallow groundwater from Japan, south Korea and east China. Geochem. J. 28, 387-410.

Nakashita, R., Suzuki, Y., Akamatsu, F., Iizumi, Y., Korenaga, T. and Chikaraishi, Y. (2008) Stable carbon, nitrogen, and oxygen isotope analysis as a potential tool for verifying geographical origin of beef. Anal. Chim. Acta 617, 148152.

Obara, N. (1961) Report on the engineering geology of the proposed dam site at Gomijima along the river Tedori, Ishikawa prefecture. Report of Geological Survey of Japan 12, 7276 (in Japanese with English abstract).

Okuyama, T. (2010) Hydrogeological survey of Tedori-gawa fan. Proceedings of the Annual Meeting of the Japanese Society of Irrigation, Drainage and Rural Engineering, 244245 (in Japanese).

Papesch, W. and Horacek, M. (2009) Forensic applications of stable isotope analysis: Case studies of the origins of water in mislabeled beer and contaminated diesel fuel. Science and Justice 49, 138-141.

Parkhurst, D. L. and Appelo, C. A. J. (1999) Users Guide to PHREEQC (Version2)-A Computer Program for Speciation, Batch-Reaction, One-Dimensional Transport, and Inverse Geochemical Calculations, Water-Resources Investigations Report, U.S. Department of the Interior, U.S. Geological Survey, 99-4259.

Suzuki, Y., Chikaraishi, Y., Ogawa, N. O., Ohkouchi, N. and Korenaga, T. (2008) Geographical origin of polished rice based on multiple element and stable isotope analyses. Food Chem. 109, 470-475.

Suzuki, Y., Nakashita, R., Akamatsu, F. and Korenaga, T. (2009)
Multiple stable isotope analyses for verifying geographical origin and agricultural practice of Japanese rice samples. Bunseki Kagaku 58, 1053-1058 (in Japanese with English abstract).

Tomita, J., Sakaguchi, A., Satake, H., Nakamura, T. and Yamamoto, M. (2004) Isotopic geochemical study of hot and mineral springs around Hakusan volcano. Annual Report of Kanazawa University 20051201, 80-81.

Tomiyama, S., Ii, H., Miyaike, S., Hattori, R. and Ito, Y. (2009) Estimation of the sources and flow system of groundwater in Fuji-Gotenba area by stable isotopic analysis and groundwater flow simulation. Bunseki Kagaku 58, 865-872 (in Japanese with English abstract).

Tomiyama, S., Ii, H., Uehara, T. and Wakita, T. (2010) Stable isotopic analysis and groundwater flow simulation as potential tools for estimating groundwater sources used for food materials. Nippon Shokuhin Kagaku Kogaku Kaishi 57, 32-39 (in Japanese with English abstract).

Tomiyama, S., Ueda, A., Kitai, A. and Aoi, S. (2011) Estimation of the sources of groundwater used for food materials in Sayama city, Saitama prefecture, by geochemical methods and numerical simulation. Bunseki Kagaku 60, 131142 (in Japanese with English abstract).

Tsuchihara, T., Yoshimoto, S., Ishida, S. and Imaizumi, M. (2011) Classification of recharge sources of groundwater in a paddy dominant alluvial fan based on geochemical and isotopic analyses. Bulletin of the National Institute for Rural Engineering 211, 21-34 (in Japanese with English abstract).

Ueki, T. (2008) Food labeling and authentification technology. Nippon Shokuhin Kagaku Kogaku Kaishi 55, 405-409 (in Japanese).

Umeda, K., Yanagisawa, K. and Yoneda, S. (1995) Construction of database of hydraulic conductivities on land of Japan. Journal of Groundwater Hydrology 37, 69-77 (in Japanese).

Waseda, A. and Nakai, N. (1983) Isotopic compositions of meteoric and surface waters in Central and Northeast Japan. Geochem. J. 17, 83-91.

Watanabe, K. (2002) Natural environment in Tedori River: Groundwater in Tedori fan. Chigakukyouiku (Geochemistry), 55, 149-172 (in Japanese). 